\title{
Trust and Betrayal in the Medical Marketplace
}

Maxwell Gregg Bloche

Georgetown University Law Center, bloche@law.georgetown.edu

This paper can be downloaded free of charge from:

https://scholarship.law.georgetown.edu/facpub/725

55 Stan. L. Rev. 919-954 (2002)

This open-access article is brought to you by the Georgetown Law Library. Posted with permission of the author. Follow this and additional works at: https://scholarship.law.georgetown.edu/facpub

Part of the Health Law and Policy Commons, Health Policy Commons, Legal Ethics and Professional Responsibility Commons, and the Medical Jurisprudence Commons 


\title{
COMMENTS
}

\section{Trust and Betrayal in the Medical Marketplace}

\author{
M. Gregg Bloche*
}

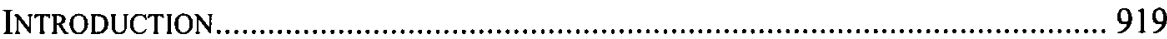

I. TRUST, BETRAYAL, AND CONTRACT IN THE HEALTH SPHERE ........................ 920

A. The Contractarian Challenge to Trust-Supporting Legal Rules........ 922

B. Selfishness-Suppressing Norms and the Case Against Contract ........ 925

C. Ex Ante Choices and "Later Selves" "............................................... 927

D. Opportunism and the "Trust Problem"........................................... 930

II. CAN THE CASE For CONTRACT BE SAVED? .................................................. 932

A. Is There a Crisis of Trust? ............................................................... 933

B. The Relationship Between Health Care Law and Trust..................... 934

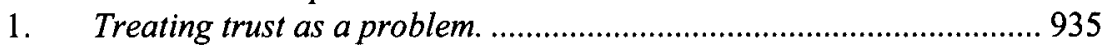

2. $\quad$ Treating trust as a virtue. .............................................................. 939

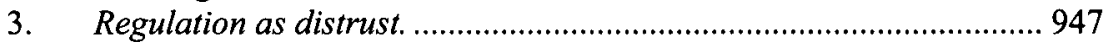

CONCLUSION: MARKETS FOR TRUST AND BETRAYAL...................................... 949

\section{INTRODUCTION}

Dr. Maris gave my mother her last laugh.1 Every week or so, Dr. Maris, dressed in black, would approach me near the nurses' station to report that my mother had said, "It's time." At issue was the expensive bag of blood clotting

* Professor of Law, Georgetown University, and co-director, Georgetown-Johns Hopkins joint program in law and public health. J.D., Yale University, 1987. M.D., Yale University, 1984. Preparation of this paper was supported in part by a Robert Wood Johnson Foundation Investigator Award in Health Policy Research. I thank Kenneth Arrow, Margaret M. Blair, Peter J. Hammer, Donald C. Langevoort, William Sage, Elyn Saks, Ellen Waldman, and participants in Georgetown University Law Center's faculty research workshop for their suggestions and Erica Pape and Elizabeth Jungman for their research assistance. Some of the ideas in this paper were presented in earlier form at a National Institutes of Health Center for Clinical Bioethics workshop on trust and a Robert Wood Johnson Foundation Investigator Awards Competition Cluster Group symposium on Kenneth Arrow's contribution to health economics.

1. The events I relate below occurred in the spring of 1997, at a nursing and hospice care facility near Baltimore. I have given the doctor a pseudonym. 
cells Dr. Maris reluctantly hung over my mother's bed every few days. The cells kept my mother alive. Leukemia had destroyed her bone marrow. She couldn't make her own blood cells, and she would bleed to death unless the little, straw-colored bags kept appearing atop her IV line.

My mother's cancer was untreatable. Johns Hopkins Hospital had discharged her, and money was a problem. But her prognosis, death within weeks, made her eligible for Medicare's hospice benefit. She was a winning economic proposition for any hospice program that would take her-unless the clotting cells were part of the bargain. But my mother insisted on them, and the hospice program that admitted her went along. Weeks, though, stretched into months. My mother did not die. Instead, she kept consuming clotting cells and incurring costs above Medicare's payment rate.

My mother stayed alert, without pain, as end-stage leukemia patients commonly do until their last hours. The first time Dr. Maris told me that my mother was "ready" for the clotting cells to stop, I went into her room girded for the final farewell. She insisted she had said no such thing, and she begged me to keep the cells coming. I did so. A week later, Dr. Maris, my mother, and I repeated this cycle. It became a routine. My mother would not behave like a "good" hospice patient. She would not go without a fight, and Dr. Maris gave her one. Dr. Maris told me that the cells were a gift, wasted on my mother since she could not be saved. My mother joked about Dr. Maris's black clothes and unrelenting efforts to close the Final Sale, until, eventually, leukemia had the final say.

Did Dr. Maris's efforts to reach this endpoint more quickly break faith with her profession's Hippocratic Oath of fidelity to patients? Maybe my mother was not entitled to the clotting cells, since Medicare's hospice benefit covered only supportive end-of-life care. ${ }^{2}$ And maybe Dr. Maris thus had no duty to provide them. If so, then perhaps Dr. Maris's penchant for reading readiness to die into whatever my mother said did not matter. Maybe my mother simply contracted out of any "right" to the clotting cells—or consented to Dr. Maris's clinical judgment about what constitutes supportive care-when she decided to use Medicare's hospice benefit. Or, maybe she kept telling Dr. Maris one thing and me another. Of one thing, though, I am sure. I felt less trust for Dr. Maris when I learned that the clotting treatments were a money-losing proposition.

\section{TRUSt, Betrayal, AND CONTRACt IN THE HEALTH SPHERE}

Anecdotes, of course, make bad policy, as both the left and the right are wont to point out when gripping stories go against them. ${ }^{3}$ Yet in recent years,

2. See 42 U.S.C.A. $\S \S 1395 \mathrm{~d}(\mathrm{~d})(2)(\mathrm{A})(\mathrm{ii})(\mathrm{I}), 1395 \mathrm{f}(\mathrm{a})(7)(\mathrm{A}), 1395 \mathrm{x}(\mathrm{dd})(1)(\mathrm{E})$ (West 2002).

3. See David A. Hyman, Lies, Damned Lies, and Narrative, 73 IND. L.J. 797, 804-07 (1998) (describing examples of anecdotes used by politicians and advocates to gain support 
the nation has seen a proliferation of stories of breach of trust, ${ }^{4}$ in the business and public sectors as well as in the health sphere. At Enron, WorldCom, and other firms, corporate fiduciaries - officers and directors-betrayed the faith of shareholders and employees by misstating earnings, unloading stock based on inside knowledge, and turning a blind eye toward bad behavior. ${ }^{5}$ The accounting industry's wholesale complicity in this misconduct ${ }^{6}$ undermined investor confidence in corporate financial reporting to a degree that has reduced the market value of publicly traded firms overall. ${ }^{7}$ Perceptions that Enron and other firms buy unfair political influence through "soft money" campaign contributions rose to a crescendo that, in 2002, produced campaign finance reform. ${ }^{8}$ In the health sector, revelations that managed care executives profited from withholding clinical services led to high-profile, nine-figure jury verdicts against health plans $^{9}$ and fed growing popular backlash against managed care..$^{10}$

for their policy proposals); Sylvia A. Law, Ending Welfare as We Know It, 49 STAN. L. REV. 471, 474-84 (1997) (cataloguing false assumptions and stereotypes that underlay the 1996 welfare reform legislation); Steven V. Roberts, Food Stamps Program: How it Grew and How Reagan Wants to Cut It Back, N.Y. TIMES, Apr. 4, 1981, § 1, at 11 (reporting on President Reagan's rhetorical use of negative stories about people receiving welfare).

4. I refer to trust here in a broad sense, encompassing a range from the deeply felt, mutual faith experienced by people in loving relationships and close friendships to the dispassionate, even "calculative" trust or confidence that facilitates business dealings among strangers and casual acquaintances. See Oliver E. Williamson, Calculativeness, Trust, and Economic Organization, 36 J.L. \& ECON. 453, 463-84 (1993) (discussing multiple understandings of trust).

5. See, e.g., Kurt Eichenwald, Enron's Many Strands: The Overview, Enron Panel Finds Inflated Profits and Self-Dealing, N.Y. TIMES, Feb. 3, 2002, § 1, at 1 (describing a report concluding that Enron "executives intentionally manipulated the company's profits, inflating them by almost $\$ 1$ billion in the year before Enron's collapse through byzantine dealings with a group of partnerships"); Simon Romero \& Alex Berenson, WorldCom Says It Hid Expenses, Inflating Cash Flow \$3.8 Billion, N.Y. TIMES, June 26, 2002, at A1 (reporting on WorldCom's announcement that "it had overstated its cash flow by more than $\$ 3.8$ billion during the last five quarters"); Simon Romero, Reports of Shredding Intensify Global Crossing Inquiry, N.Y. TIMES, June 25, 2002, at C11 (reporting on Global Crossing's "acknowledgment that employees at several of its offices had shredded documents after the Securities and Exchange Commission began investigating the company in February").

6. See Carrie Johnson \& Peter Behr, Andersen Guilty of Obstruction; Accounting Firm Will End Audit Work, WASH. POST, June 16, 2002, at Al ("Andersen, as Enron's auditor, signed off on financial statements that obscured billions of dollars in debts and losses at the energy-trading giant .....").

7. See Alex Berenson, The Nation: Oversight; The Biggest Casualty of Enron's Collapse: Confidence, N.Y. TIMES, Feb. 10, 2002, $\S 4$, at 1 ("Already, even a hint of an accounting irregularity can cause Wall Street to flee a company's bonds and stocks en masse."); Gretchen Morgenson, What If Investors Won't Join the Party?, N.Y. TIMES, June $2,2002, \S 3$, at 1 ("The steady stream of accounting scandals, corporate chicanery and questionable practices at Wall Street firms is taking a toll on investor confidence - and that has major implications for the stock market as a whole.").

8. See Bipartisan Campaign Reform Act of 2002, Pub. L. No. 107-155, 116 Stat. 81.

9. See, e.g., \$120 Million Award Against Aetna Stands, L.A. TIMES, Mar. 30, 1999, at C2.

10. Mark A. Peterson, Introduction: Politics, Misperception, or Apropos?, 24 J. 
The trustworthiness of physicians who receive monetary rewards for withholding costly treatments has become a focus of federal and state litigation. ${ }^{11}$

\section{A. The Contractarian Challenge to Trust-Supporting Legal Rules}

Whether these accounts of breach of faith and loss of confidence reflect a real drop in trust and trustworthiness or increased attention to longstanding phenomena is unclear. ${ }^{12}$ Either way, they come at an embarrassing point for many legal scholars. For a generation or more, writers in the Chicagoan tradition have challenged traditional limits on actors' ability to contract out of-or otherwise escape-legal rules that purport to safeguard trustworthiness. In the business law context, some commentators have urged that corporate officers and directors be permitted to opt out of fiduciary duties. ${ }^{13}$ Capital markets, these scholars contend, can be counted upon to select the most efficient management and board oversight practices, and legal rules aimed at preserving trust too often stand in the way. The contractarian critique of trust-

HEALTH POL. POL'Y \& L. 873, 875-76 (1999). Since the late 1990s, erosion of trust has been a central theme in press coverage of the health care industry. See, e.g., Marketplace Features: Trust in the Medical Realm (WGBH radio broadcast, June 26-28, 2002), available at http://marketplace.org/features/trust. Negative characterizations of managed care bureaucrats have also become a staple in popular entertainment. See, e.g., JOHN Q (Evolution Entertainment 2002).

11. See, e.g., Pegram v. Herdrich, 530 U.S. 211, 216 (2000) (concerning whether HMOs breach their fiduciary duties under the Employee Retirement Income Security Act (ERISA) by offering physicians financial incentives to limit medical care); Shea v. Esensten, 622 N.W.2d 130, 134-36 (Minn. Ct. App. 2001) (concerning whether a medical malpractice plaintiff can introduce evidence bearing on physicians' financial incentives). For discussions of judicial treatment of financial incentives to practice medicine more frugally, see PETER D. JaCobson, Strangers in the Night: LaW and Medicine in the Managed Care ERa 22249 (2002); M. Gregg Bloche \& Peter D. Jacobson, The Supreme Court and Bedside Rationing, 284 JAMA 2776, $2776-79$ (2000); Peter J. Hammer, Pegram v. Herdrich: On Peritonitis, Preemption, and the Elusive Goal of Managed Care Accountability, $26 \mathrm{~J}$. HEALTH POL. POL'Y \& L. 767, 769-76 (2001).

12. There has been much discussion in recent years concerning the so-called "bowling alone" hypothesis, the proposition that America's stock of "social capital"-our degree of civic engagement, social connectedness, and interpersonal trust-has been in decline for the past fifty years or more. See generally RoBERT D. PUTNAM, Bowling Alone: THE COLLAPSE AND REVIVAL OF AMERICAN COMMUNITY (2000) (presenting exhaustive evidence of such decline).

13. See, e.g., Henry N. Butler \& Larry E. Ribstein, Opting Out of Fiduciary Duties: A Response to the Anti-Contractarians, 65 WASH. L. REV. 1, 71 (1990) ("[C]orporate rules ultimately are and, from an efficiency perspective, should be the product of private ordering, not government regulation. Even where liability rules are appropriate, they should be regarded as standard form contractual provisions that can be drafted around."); Frank $\mathrm{H}$. Easterbrook \& Daniel R. Fischel, Voting in Corporate Law, 26 J.L. \& ECoN. 395, 401-03 (1983) (asserting that "[t]he standby rule of corporate law, the fiduciary principle, requires actors to behave in the way that they would have agreed to do by contract, if detailed contracts could be reached and enforced at no cost"). 
supporting legal norms has extended to the intimate sphere. Family law doctrines that limit free movement into and out of loving commitment have been condemned as obstacles to personal fulfillment. ${ }^{14}$

Nowhere has the contractarian attack on trust-supporting legal rules been stronger, or more successful in changing the law, than it has been in the health sphere. Since the mid-1970s, market-oriented scholars have challenged a broad range of legal principles previously assumed to sustain the trustworthiness of physicians and health systems. Doctrines shielding physicians from antitrust law, insulating them from insurers' and hospitals' influence over clinical practice, and reinforcing the precept of undivided clinical loyalty to patients came under attack as protection for the medical profession at consumers' expense. ${ }^{15}$ These scholars, including Clark Havighurst, Richard Epstein, and Mark Hall, urge contractual ordering of clinical standards of care; 16 relationships among physicians, hospitals, and health care payers; ${ }^{17}$ and physicians' conflicting obligations to patients, payers, and other third parties. ${ }^{18}$

Although courts have not embraced this approach wholesale, they have pushed health care law far in this direction since the 1970s. The United States Supreme Court's 1975 rejection of a "learned professions" exemption from federal antitrust law ${ }^{19}$ not only commenced a judicial offensive against physicians' efforts to limit price competition; ${ }^{20}$ it opened the way for use of antitrust doctrine to stop professional self-regulation of physicians' business relationships. $^{21}$ Courts have eviscerated laws barring lay management of medical decisionmaking, ${ }^{22}$ allowed insurers to offer financial rewards to

14. See Milton C. Regan, JR., Alone Together: Law and the Meanings of MARRIAGE 33-86 (1999) (criticizing contractarian approaches to marriage and divorce).

15. James F. Blumstein \& Frank A. Sloan, Redefining Government's Role in Health Care: Is a Dose of Competition What the Doctor Should Order?, 34 VAND. L. REv. 849 (1981); Clark C. Havighurst, Competition in Health Services: Overview, Issues and Answers, 34 Vand. L. Rev. 1117 (1981); Clark C. Havighurst, Doctors and Hospitals: An Antitrust Perspective on Traditional Relationships, 1984 DUKE L.J. 1071 (1984).

16. Clark C. Havighurst, Health Care Choices: Private Contracts as INSTRUMENTS OF HEALTH REFORM 227-62 (1995); Richard A. Epstein, Medical Malpractice: The Case for Contract, 1 AM. B. Found. Res. J. 87 (1976); E. Haavi Morreim, Cost Containment and the Standard of Medical Care, 75 CAL. L. REV. 1719, 1745-63 (1987).

17. Mark A. Hall, Institutional Control of Physician Behavior: Legal Barriers to Health Care Cost Containment, 137 U. PA. L. Rev. 431, 447-49 (1988).

18. Mark A. Hall, Rationing Health Care at the Bedside, 69 N.Y.U. L. REv. 693, 699700 (1994).

19. See Goldfarb v. Va. State Bar, 421 U.S. 773, 787-93 (1975) (holding that providers of professional services engage in "trade or commerce" and are thus subject to federal antitrust law).

20. Clark C. Havighurst, Health Care as a (Big) Business: The Antitrust Response, 26 J. HEALTH POL. POL'Y \& L. 939, 941 (2001).

21. Peter J. Hammer, Medical Antitrust Reform: Arrow, Coase, and the Changing Structure of the Firm, in The Privatization of Health Care Reform: Legal \& ReGUlatory PERSPECTIVES 113-157 (M. Gregg Bloche ed., 2002).

22. Adam M. Freiman, The Abandonment of the Antiquated Corporate Practice of 
physicians for withholding costly tests and treatments, ${ }^{23}$ and empowered employee benefits managers and health plans to contract for standards of care below those set by the medical profession. 24

This contractarian remodeling of the law of health care provision entailed rejection of an older wisdom. The older wisdom drew a distinction between medical professionalism and the rule of the marketplace, disdained economic competition as beneath professional dignity, demanded that physicians adhere to an ethic of fidelity to patients regardless of self-interest, and insisted on professional insulation from lay influences (public or private) on clinical judgment. ${ }^{25}$ Adherents held that this understanding of professional obligation protected patients against exploitation, rewarded physicians with social respect, and thereby sent patients a strong message of trustworthiness. Trustworthiness mattered, this story held, because it encouraged patients to volunteer intimate facts about their lives, cooperate with diagnosis and treatment, draw reassurance from medical explanations, and experience the doctor-patient relationship itself as empowering and comforting.

A classic article by Kenneth Arrow forty years ago conceptualized this thinking in economic terms. ${ }^{26}$ Arrow argued, in essence, that physicians' anticompetitive cultural norms and ethic of fidelity to patients were a social welfare-enhancing response to the problem of information imbalance between medically ignorant patients and comparatively well-informed physicians. ${ }^{27}$ The ethic of self-sacrificing fidelity reduced the risk of opportunistic exploitation of this knowledge asymmetry, Arrow held. By signaling their commitment to this ethic, he contended, physicians assuaged patients' fears of being exploited; this encouraged patients to rely upon and benefit from medical care. ${ }^{28}$ Signaling behaviors were crucial to Arrow's account. Prohibitions against overt profitseeking, avoidance of conflicts of interest, and provision of charity care sent the

Medicine Doctrine: Injecting, a Dose of Efficiency into the Modern Health Care Environment, 47 EMORY L.J. 697, 704-12 (1998).

23. See Pegram v. Herdrich, 530 U.S. 211, 237 (2000) (holding that treatment decisions by HMO physicians are not fiduciary acts under the Employee Retirement Income Security Act (ERISA) and therefore rejecting claim that giving financial rewards to these physicians for frugal practice breaches ERISA's fiduciary duty provisions); Neade v. Portes, 739 N.E.2d 496, 499-502 (Ill. 2000) (holding that giving financial rewards to physicians for frugal practice does not breach these physicians' common law fiduciary duties).

24. The United States Supreme Court's two major opinions on managed care, Pegram, 530 U.S. 211, and Rush Prudential HMO, Inc. v. Moran, 122 S. Ct. 2151 (2002), indicate that if restrictions on medical coverage and care are set forth explicitly in ERISA plan descriptions, they are immune from challenge under state tort law (which typically defers to professional custom to set standards of care).

25. See, e.g., Talcott Parsons, The Social System 428-65 (1951).

26. Kenneth J. Arrow, Uncertainty and the Welfare Economics of Medical Care, 53 AM. ECON. REV. 941 (1963).

27. Id. at $965-66$.

28. Id. 
message that medicine was worthy of trust as a culture apart from the selfseeking mores of the marketplace. ${ }^{29}$

Contemporary market-oriented scholars of health law and policy reject Arrow's account as "layered in amber"30_dated by its inattention to professional self-interest and its deference to professional norms against advertising and entrepreneurship. In support of their contractarian policy prescriptions, they point to the self-serving features of professional constraints on consumer choice, and they contend that the information asymmetry Arrow described no longer merits (if it ever did) privileging professional norms over health care buyers' choices. ${ }^{31}$ These choices, made before the onset of medical need, from among health plans with competing approaches to management of care and costs, honor consumers' tradeoffs between medical care and other wants and needs, the contractarian story holds. ${ }^{32}$

\section{B. Selfishness-Suppressing Norms and the Case Against Contract}

These contractarian authors are at a loss to explain the popular backlash against managed care-and its intrusions upon professional authority-that began in the mid-1990s. They condemn political candidates' anti-HMO rhetoric, large jury verdicts against health plans, and aggressive state regulators, ${ }^{33}$ but they offer no accounting for the rising anger that generated these responses. Nor have they engaged a growing body of research on the psychology of trust, altruism, and health risk that casts doubt on the contractarian paradigm for health law. This work suggests that making some commitments and behaviors a matter of choice, rather than status-based obligations, can interfere with the cognitive and emotional processes by which people hold to their commitments. Structures of moral belief (and feelings

29. Arrow's account of information asymmetry (concerning medicine's biological efficacy) as the source of patients' desire for professional trustworthiness left out the affective and intrinsic dimension-patients' yearning for support, comfort, and empowerment through emotional connection with their physicians. M. Gregg Bloche, The Market for Medical Ethics, 26 J. HEALTH POL. POL'Y \& L. 1099, 1108 (2001).

30. Peter J. Hammer, Deborah Haas-Wilson \& William M. Sage, Kenneth Arrow and the Changing Economics of Health Care: "Why Arrow? Why Now?," 26 J. HEALTH POL. POL'Y \& L. 835, 835 (2001).

31. E. Haavi Morreim, Holding Health Care accountable: Law and the New MEDICAL MARKETPLACE (2001); James C. Robinson, The End of Asymmetric Information, 26 J. Health Pol. Pol'y \& L. 1045, 1051-52 (2001); see also Frank A. Sloan, Arrow's Concept of the Health Care Consumer: A Forty-Year Retrospective, 26 J. HEALTH POL. POL'Y \& L. 899, 910 (2001) (urging that health policy and law not treat consumer ignorance as a given, and instead take up the challenge of making medical consumers into betterinformed decisionmakers).

32. See, e.g., Richard A. EPSTEIn, Mortal PERIL: OUR INALIENABle Right to Health Care? 65-76 (1997).

33. Id. at 425-29; David A. Hyman, Managed Care at the Millennium: Scenes from a Maul, 24 J. HeAlTH POL. POL'Y \& L. 1061 (1999). 
about these beliefs ${ }^{34}$ ) are to some degree rigid. ${ }^{35}$ Allowing some elements to vary, via contract, can make these structures less stable, eroding people's capacity to honor their commitments. This has troublesome implications for people's trust, trustworthiness, and reliability when matters of duty are made into matters of choice.

Do these implications imperil the contractarian vision of health law and policy? Outside the health sphere, contract-skeptics argue that the new learning about the psychology and economic value of trustworthiness weighs against permitting parties to contract out of extant norms of fidelity. 36 "Progressive" corporate law scholars stress the central role of cooperative social norms in negotiating the myriad prisoner's dilemma situations that pose obstacles to value-adding collaboration between a firm's employees, managers, and shareholders. ${ }^{37}$ These norms, they contend, are powerfully reinforced by fiduciary and other legal principles from which corporate stakeholders cannot contractually depart. ${ }^{38}$ Legal enforcement of these principles, the argument holds, plays less of a role in giving them effect than does their internalization by corporate agents and stakeholders. ${ }^{39}$ Deterrence via legal threat-or even through informal sanctions like fear of retaliation or loss of reputation-is not

34. See generally ANTonio R. DAMASIo, Descartes' ERror: Emotion, REASON, AND THE HUMAN BRAIN (1994) (discussing the influence of affect on people's beliefs and judgments); George F. Loewenstein, Elke U. Weber, Christopher K. Hsee \& Ned Welch, Risk as Feelings, 127 PSYCHOL. BuLl. 267 (2001) (arguing that feelings mediate the connection between cognitive evaluations of risk and risk-related behavior).

35. See Avner Ben-Ner \& Louis Putterman, Values and Institutions in Economic Analysis, in ECONOMICS, VALUES, AND ORGANIZATION 1, $27-37$ (Avner Ben-Ner \& Louis Putterman eds., 1998) (arguing the "psychological traits may well occur in bundles of expressed behavior that are not decomposable" and that some "components" of a bundle that is favored by biological or cultural selection pressure may, by themselves, be maladaptive). For a comprehensive review of the role of such structural constraints in biological evolution, see StePhen Jay Gould, The Structure of Evolutionary Theory (2002). This structuralist approach to thinking about social (and biological) change is at odds with welfare economists' propensity to formulate functionalist rationales for all behavior, without regard for possible limits on its "decomposibility."

36. See, e.g., Lawrence E. Mitchell, The Importance of Being Trusted, 81 B.U. L. REv. 591 (2001).

37. See Progressive Corporate Law (Lawrence E. Mitchell ed., 1995); Margaret M. Blair \& Lynn A. Stout, A Team Production Theory of Corporate Law, 85 VA. L. REV. 247 (1999). These prisoner's dilemma situations include the agency cost problems muchdiscussed in corporate law (arising from managers', directors', and employees' incentives to further their own interests at the firm's expense) and the so-called "team production" problem-the mutual reluctance of a firm's agents and stakeholders to invest effort and money in common endeavors that render the participants vulnerable to each others' opportunism. Not all collaboration, of course, adds value from an overall social welfare perspective: Antitrust and anticorruption measures aim to reduce socially destructive collaboration.

38. Margaret M. Blair \& Lynn A. Stout, Trust, Trustworthiness, and the Behavioral Foundations of Corporate Law, 149 U. PA. L. REV. 1735, 1785-89 (2001).

39. Id. at 1793-96. 
nearly as important an influence on behavior as is the adoption of cooperative norms as personal preferences. ${ }^{40}$ Through symbolic affirmation of these norms, law sends the message that a firm's participants ought to adopt them as preferences. 41 Allowing corporate agents and stakeholders to contract out of fiduciary duties would deliver the contrary message that nonadoption is an acceptable choice. This not only undermines belief in the "rightness" of the particular fiduciary duties at issue; it risks weakening the psychological mechanisms that inculcate selfishness-suppressing norms more generally. ${ }^{42}$

\section{Ex Ante Choices and "Later Selves"}

This case against contract, when selfishness-suppressing norms are at stake and the possibilities for opportunism are great, poses a large challenge for proponents of market ordering in the medical realm. This challenge is all the greater because of a feature of health care contracts that distinguish them from other market-mediated commitments, including corporate governance. More than any other contractual commitments, the medical coverage arrangements defended by proponents of market ordering deny what Jon Elster calls the freedom of choice of "later selves." 43 These arrangements cope with one of

40. Id. at 1794-98. Some skeptics of law's capacity to encourage people to adopt cooperative norms as personal preferences argue that law's coercive force "crowds out" people's inclination toward voluntary cooperation. See infra text accompanying notes 12438 .

41. Cf. Cass R. Sunstein, On the Expressive Function of Law, 144 U. PA. L. Rev. 2021 (1996) (exploring law's possibilities and limits as a tool for inculcating normative beliefs).

42. This line of argument conflates two sorts of preferences - desire and a sense of duty. Its proponents point to a body of behavioral science research consistent with the proposition that people manifest distinct, "self-regarding" and cooperative (or "otherregarding") personalities, elicited by different environmental cues and contexts. See Blair \& Stout, supra note 38, at 1759-80 (reviewing experimental studies of cooperative and trusting behavior in different social contexts). Our "other-regarding" self, the argument holds, genuinely wants what is good for the other. The sense of duty, by contrast, often runs contrary to our desires. Cf. Jane Mansbridge, Starting with Nothing: On the Impossibility of Grounding Norms Solely in Self-Interest, in ECONOMICS, VALUES, AND ORGANIZATION, supra note 35, at 151, 155-62 (distinguishing between the capacity "to make another's good one's own" and the capacity "to act against one's preferences on the ground that one ought so to act"). This distinction is important for the law, since different mental mechanisms are affected differently by the law's intervention. Behavioral science is agnostic as to mental mechanisms, but psychoanalytic models hold that distinct mechanisms are involved in (1) the empathic connection that activates our "other-regarding" self and (2) the self-denying, judgmental psychology of duty. An illustration, all too timely, is the corporate official who is drawn, out of concern for a colleague, into complicity in misstating earnings but who loses sleep at night over the tension between this "other-regarding" preference and her duty to shareholders. In general, law's impersonality and coerciveness make it a poor tool for encouraging behaviors that are engendered by empathic connection with others. These characteristics of law, though, make it a better tool for supporting behaviors that arise from a tough-minded sense of duty.

43. Jon Elster, Introduction to ThE MULTIPLE SELF 1 (Jon Elster ed., 1985); M. Gregg Bloche, The Invention of Health Law, 91 CAL. L. REV. (forthcoming 2003). 
health care policy's central dilemmas, the management of costs in the face of the "moral hazard" of insurance, by precommitting health care purchasers to methods of spending restraint that apply when illness arises. All contracts, of course, involve a measure of precommitment to behavioral constraints. But the precommitment called for in medical coverage contracts is unique. Consumers agree, when they buy coverage (typically while healthy), to limits that apply most poignantly to profoundly different "later selves." 44 Mere apprehension of serious illness transforms us: It makes us afraid and causes us to regress to childlike states of dependence and wishful thinking. ${ }^{45}$ Diagnosis of serious illness furthers this transformation, as do disabling symptoms.

Health care contractarians point to this transformation as good reason for holding the sick to their ex ante choices. Consumers choosing from among medical coverage plans reside behind a Rawlsian veil of ignorance, uncertain about their future health needs. ${ }^{46}$ Cost-conscious purchasing decisions made from behind this veil, contractarians hold, are fairer measures of people's costbenefit tradeoffs than are the retrospective wishes of sick patients who have lost their bets and want to escape the consequences. ${ }^{47}$ But the transformation involved is more than mere ex post regret after loss of a gamble. The fear and regression it entails create "later selves" with quite different preferences and felt needs-needs not imagined ex ante. Whether holding these "later selves" to the consequences of ex ante health care choices furthers or reduces either social welfare or personal autonomy is an open question. 48

44. The marriage contract arguably equals or exceeds health insurance in its precommitment of very different "later selves." But in the United States and many other nations, unilateral, "no-fault" exit from marriage is an option, typically available without the need to pay contractual damages. This attenuation of the law's protection for reliance interests in marriage has ensued from divorce law's heightened concern for the freedom of choice of "later selves."

45. Eugene Halpert, Asclepius: Magic in Transference to Physicians, 63 Psychoanalytic Q. 733, 751-54 (1994); Herman Nunberg, Psychological Interrelations Between Physician and Patient, 25 Psychoanalytic Rev. 297, 300 (1938); William M. Zinn, Transference Phenomena in Medical Practice: Being Whom the Patient Needs, 113 ANNALS INTERNAL MED. 293, 295 (1990).

46. This veil is to some degree translucent (unlike a true Rawlsian veil of ignorance), since many consumers know something about their future health needs, owing to family histories, lifestyle, and environmental risks, and chronic conditions already diagnosed. Adverse selection ensuing from this knowledge is a major source of medical insurance market failure. Sherry Glied, Managed Care, in 1 HANDBOOK OF HEALTH ECONOMICS 707, 721-23 (Anthony J. Culyer \& Joseph P. Newhouse eds., 2000).

47. EPSTEIN, supra note 32; at 68-69.

48. Health care contractarians answer emphatically that privileging medical consumers' ex ante choices both respects their autonomy and makes medical resource allocation more rational. The Rawlsian veil of ignorance argument, they contend, favors the ex ante vantage point as the locus of consumers' most reasonable, dispassionate health care choices, and a robust conception of personal autonomy and responsibility demands that sick patients be held to these ex ante choices. An alternative view holds that our transformed "later selves" merit at least equal regard as persons-perhaps greater regard because of what they have come to know and feel-and that giving the ex ante perspective trump authority 
This discussion presumes all parties' ability to determine, with clarity, the ex post medical consequences of health care consumers' ex ante choices. But such clarity is often absent. Uncertainty and ensuing discretion pervade the determination of health care benefits. ${ }^{49}$ The "medical necessity" standard that is a staple of health insurance contracts defers to physician practice norms to determine coverage. ${ }^{50}$ Doctors' practice styles, however, vary widely: Different physicians commonly evaluate and treat clinically similar patients in very different ways. More often than not, the available scientific data cannot resolve the question of which of multiple therapeutic (or diagnostic) methods is most effective, let alone shed light on the comparative cost-benefit profiles of alternative methods. 51 Thus the "medical necessity" test for coverage provides opaque cover for enormous discretion-and a wide opening for insurer opportunism. More pointed contractual guidance concerning cost-benefit tradeoffs (e.g., maximum dollar amounts payable to save a quality-adjusted life year ${ }^{52}$ ) could in theory reduce the scope of insurers' discretion, but the paucity of scientific measures of expected therapeutic : efficacy 53 would ensure continued wide discretion in practice.

therefore undermines respect for personal autonomy. See generally JON ELSTER, ULYSSES AND THE SIRENS: StUdies IN RATIONALITY \& IRRATIONAlitY 36-65 (2d ed. 1984) (discussing cognitive mechanisms involved in precommitment and considering ethical issues posed by subsequent preference change). Conflict between these approaches to the ethical priority of ex ante versus ex post medical choices underlies a variety of controversies in the law of health care provision, including the debate over whether informed consent law should require disclosure of all medically accepted diagnostic and therapeutic options (however defined) or merely all options provided by a health plan.

49. See Bloche, supra note 43.

50. See Rush Prudential HMO, Inc. v. Moran, 122 S. Ct. 2151, 2170 (2002) (concluding that independent review of HMO determinations of medical necessity, under state laws mandating such review, relies upon physicians' professional judgment and is akin to a medical "second opinion"). Specific coverage exclusions (e.g., those for investigational treatments, mental illness, or organ transplants) leave less room for uncertainty and insurer discretion. But the considerable volume of litigation concerning these exclusions confirms that they hardly eliminate uncertainty and discretion. See, e.g., Phillips v. Lincoln Nat'l Life Ins. Co., 978 F.2d 302, 310-11 (7th Cir. 1992) (rejecting insurer's characterization of organic brain syndrome as a "mental illness" on ground that the term "mental illness" as used in the insurance contract to limit benefits was ambiguous and should therefore be construed in favor of the insured); Reilly v. Blue Cross \& Blue Shield United, 846 F.2d 416, 426 (7th Cir. 1988) (holding that there were material issues of fact as to whether insurer's characterization of in vitro fertilization as "experimental" and thus not covered was arbitrary).

51. See Bloche, supra note 43.

52. Characterization of health care's benefits in terms of quality-adjusted life years (QALYs) is broadly appealing to health economists because it folds medical care's myriad subjective benefits into a single metric that also incorporates extension of life. But the task of valuing these subjective benefits-such things as pain relief, reassurance, and levels of physical and psychological functioning-is fraught with indeterminacies and moral dilemmas. Id. For discussion of fairness issues posed by the QALY approach, see A. Williams, Economics, QALYs, and Medical Ethics: A Health Economist's Perspective, 1 JOURNAL D'ECONOMIE MEDICALE 49 (1997).

53. Commentators on health law and policy often urge a robust program of publicly 


\section{Opportunism and the "Trust Problem"}

Discretion, poorly scrutinized, invites opportunism, ${ }^{54}$ and for the reasons reviewed above, sick people are singularly ill-situated to monitor the exercise of medical discretion. Health care contractarians have offered no answer to this monitoring problem aside from calls for better-informed patients and medical purchasers. Selfishness-suppressing requirements-fiduciary obligation, 55 duties of good faith, and other cooperation-favoring principles 56 _are the law's classic response to such monitoring problems. If the emerging psychological understanding of how these legal requirements shape behavior is correct, they work in large measure by inducing target subjects to internalize selfishnesssuppressing norms.

People who internalize a set of norms believe that these norms are right or good, and that violating them is wrong. ${ }^{57}$ They do not see themselves as

and/or privately funded clinical outcomes research to close the gap in our knowledge about the efficacy of medical care. Serious obstacles confront such a program. The "gold standard" for such research is the randomized, controlled clinical trial. Retrospective studies draw upon preexisting clinical data, which are often collected inconsistently, on-the-fly, with insurance reimbursement and liability avoidance in mind. They are thus more likely to detect false correlations and to miss true causal connections, and they do not permit isolation of particular variables for manipulation and measurement. Prospective, controlled trials reduce these sources of error by allowing researchers to hold background variables more or less constant (through selection of clinically homogeneous patients), permitting the researchers to vary (in consistent fashion) only one or a few experimental factors, and allowing consistent measurement of preselected dependent (outcome) variables.

But these advantages come at great cost. The need for clinically homogeneous patients often excludes most of those for whom a treatment under study might be appropriate. This makes clinical trial results dubiously relevant for many, perhaps most, "real world" patients. Moreover, such research is often enormously expensive, owing to the large sample sizes (and collaboration between multiple research centers) necessary to detect small differences in the efficacy of treatment alternatives. In addition, current ethical rules prohibit use of clinical trials to measure the therapeutic value added by a more costly treatment option, once the more costly option has been determined to be more effective (in an absolute sense). Meanwhile, poorly tested, technology-intensive therapies proliferate, nurtured by widespread feelings that insurers should cover hope-giving, potentially life-saving innovations without begrudging their cost. It is therefore unlikely that clinical outcomes research will ever provide decisive scientific answers to more than a small portion of the medical questions doctors face in their daily practice. Bloche, supra note 43.

54. See Robert Cooter \& Bradley J. Freedman, The Fiduciary Relationship: Its Economic Character \& Legal Consequences, 66 N.Y.U. L. REv. 1045, 1046-47 (1991) (analyzing fiduciary duties in diverse legal spheres as policy responses to inability to monitor or control agents' exercise of discretion).

55. Id.

56. Another example is nonprofit corporation law's proscription against distributing earnings to stakeholders. See Henry B. Hansmann, The Role of Nonprofit Enterprise, 89 YALE L.J. 835, 838, 843-45 (1980) (arguing that the nonprofit form's bar against distribution of an enterprise's income except as reasonable compensation for goods, services, or money loaned protects the enterprise's patrons-its customers or donors-against opportunism arising from patrons' inability to monitor the enterprise's outputs).

57. Some psychoanalytic theorists have modeled commitment to professional norms as 
choosing to adopt these norms, any more than a person of religious faith sees herself as choosing to believe that God exists. A person might wish to become a religious believer, and she thus might elect to undergo a series of experiences-attending church services, for example-in the hope of eventually acquiring faith in God. But as Bernard Williams has noted, one cannot both believe something to be true (e.g., that God exists) and think that this belief ensues from a decision to adopt it. ${ }^{58}$ The initial decision to adopt the belief must somehow submerge below the waterline of conscious awareness. Belief that something is true or right is antithetical to the idea that the belief at issue is a choice from among acceptable options.

Allowing individuals to contract out of a legal duty thus subverts the law's message that the rule imposing the duty is right. This, in turn, undermines the legal duty's power to shape beliefs and behavior. There is a crucial spillover effect here. The very existence of an option to exit from a legal duty subverts the duty's behavioral influence, even for those who do not opt out.59 Permitting individuals or firms to contract out of fiduciary or other selfishnesssuppressing duties thus imperils industrywide commitment to the cooperative behaviors these duties affirm. Health care contractarians have not answered this far-reaching challenge. The "trust problem," as Mark Hall notes in his groundbreaking article, Law, Medicine, and Trust, "is a fundamental obstacle to actualizing market advocates' vision of how health law and medical markets should function." 60

an entirely noncognitive process, arising from the experience of hierarchy during professional socialization. Eric Marcus has observed that professional trainees are put at the bottom of a hierarchy and expected to obey. To the trainee, Marcus says, the ultimate threat is made plain: "You do this because I say so. I know more than you. If you disobey I will end your career!" Eric Marcus, The Role of Liaison Psychiatry in the Clinical Training of Medical Students: A Psychoanalytic Approach, in CONSULTATION-Liaison Psychiatry: CURRENT TRendS AND New Perspectives 267, 274 (Jerry B. Finkel ed., 1983). Confronted (for the most part unconsciously) with this threat, the trainee yields, unconsciously incorporating her superiors' mores and norms into her own value system. The result is a system of normative belief less responsive to subsequent learning and experience than are beliefs adopted consciously, in a more cognitive or rational manner. One could complement Marcus's account of norm inculcation via hierarchy and threat with a parallel, equally noncognitive account of norm adoption via group membership, fear of being cut off from webs of connectedness among peers, and ensuing incorporation of group norms. Norms inculcated in this fashion will be similarly resistant to subsequent experience. These noncognitive methods of learning prepare trainees well to resist subsequent pressures (financial and otherwise) from private or state institutions to act improperly (assuming that the norms inculcated are the appropriate reference point for assessing the propriety of the conduct at issue). They are, however, poor preparation for the exercise of independent, critical judgment amidst promotional claims by pharmaceutical firms, medical equipment manufacturers, managed health plans, hospitals, and other service suppliers.

58. Bernard Williams, Problems OF THE Self 136-51 (1973) (discussing paradoxes involved in the notion of "deciding to believe").

59. See sources cited supra note 37.

60. Mark A. Hall, Law, Medicine, and Trust, 55 STAN. L. Rev. 463, 497 (2002). 


\section{II.. CAN THE CASE For CONTRACT BE SAVED?}

Can the case for contract be saved? Hall's article is a bold attempt to do so. To this end, he takes the measure of the new behavioral science thinking about law's connection to unselfish conduct. His perspective is hardly disinterested. Hall may be the most radical of the health care contractarians, and he is surely the most original. In a provocative body of work over the past fifteen years, he has argued not only for stratified levels of care linked to willingness (and ability) to pay-and for a hands-off regulatory stance toward health plans' management practices and contractual exclusions ${ }^{61}$ _ but also for giving physicians primary responsibility for health care rationing. 62 His case for bedside rationing by doctors and against laws mandating disclosure of health plans' financial rewards to physicians for withholding care sets him apart from most health care contractarians. Richard Epstein, ${ }^{63}$ Clark Havighurst, ${ }^{64}$ and others ${ }^{65}$ emphasize the ex ante specification of cost-benefit tradeoff rules and strict adherence to these rules - by health plans, doctors, and patients-when medical need arises. They aspire to constrain clinical discretion, whereas Hall seizes upon this discretion as a cost control opportunity. Doctors are better positioned than utilization managers to weigh costs against potential benefits for individual patients, he argues, and detailed rules are an obstacle to achieving the efficiencies that bedside discretion offers. Hall's cost-containment program pointedly rejects the traditional medical ethics premise that the doctor has a duty of fidelity to her patients. ${ }^{66}$ And his program is endangered, indeed ruled out, by the legal persistence, let alone

61. Mark A. Hall \& Gerard F. Anderson, Health Insurers' Assessment of Medical Necessity, 140 U. PA. L. REv. 1637, 1684-85 (1992).

62. Hall, supra note 18, at 699.

63. EPSTEIN, supra note 32, at 59-76.

64. HAVIGHURST, supra note 16 , at 185-200.

65. Other influential contractarian voices in the health sphere include E. Haavi Morreim, James Blumstein, Alan Sykes, and David Hyman. See generally MorREIM, supra note 31; James F. Blumstein, Health Care Reform and Competing Visions of Medical Care: Antitrust and State Provider Cooperation Legislation, 79 CORNELL L. REv. 1459 (1994); Richard A. Epstein \& Alan O. Sykes, The Assault on Managed Care: Vicarious Liability, ERISA Preemption, and Class Actions, 30 J. LEGAL STUD. 625 (2001); Hyman, supra note 33.

66. The physician, for Hall, should have no personal loyalty or particularized concern for her patient - no moral bias toward her patient's needs when they are weighed against the needs of others in the insurance risk pool. Hall's physician-rationer should be loyal to the risk pool. There is a paradox here. Hall endorses financial rewards to physician-rationers for withholding care: Indeed this is his contractarian tool for attracting doctors to the resource allocation role he envisions for them. Hall approves of physician responsiveness to these incentives: His allocative strategy is to get these incentives "right" from a utilitarian perspective. Thus the physician, it would seem, has no moral duty to the risk pool after all, any more than she has a duty of loyalty to her patients. She is morally free to respond, like any other seller, to the market's material possibilities. Indeed, Hall's cost containment vision relies on her doing so. 
strengthening, of physicians' fiduciary obligations to patients. Hall therefore has even more at stake than do other health care contractarians in the debate over the future of fiduciary and other selfishness-suppressing legal duties.

\section{A. Is There a Crisis of Trust?}

Hall's article is a work of extraordinary reach. It engages large bodies of scholarly and empirical literature on trust and cooperation in the health sphere and more generally. It applies insights from this literature to broad areas of the law of health care provision and to other bodies of law that bear on trust. It is carefully hedged. Hall is superb at anticipating his critics, and the propositions he advances about the law are framed in disarmingly tentative fashion. Hall, though, has a core message. It is: (1) that much of what law does, or might do, to enhance actors' trustworthiness and to nurture trust is unnecessary or even corrosive of trust; and (2) that where the law takes a hands-off stance toward the health care industry, this stance is both explicable and justifiable as a response to an excess of trust and to a consequent risk of overreaction to betrayal. Trust and trustworthiness, in short, are not in particularly short supply. To the contrary, Hall claims, trust is commonly present in excess. Regulation of the medical marketplace, and other markets, is therefore often unneeded on trust-related grounds. And, when trust is desirable, regulation frequently undermines it.

Basing the case against regulation on a surfeit of trust is a novel approach. The claim that regulation undermines trust and trustworthiness when they are in limited supply and worth preserving has been made before by market-oriented scholars. ${ }^{67}$ But the notion that concerns about loss of trust are overblown is contrary to standard wisdom in health care 68 and other policy spheres. And the proposition that trust is in excess supply is rarely heard, outside the contexts of public corruption, ${ }^{69}$ antitrust law, and other precincts that pose the problem of cooperation among some at the expense of the welfare of the many.

Is Hall's rebuilt case for contract—and against most extant and proposed regulatory constraints on market ordering in the medical sphere-persuasive? Its derring-do is sure to cheer free marketeers, dispirited in recent years by

67. See, e.g., Mark A. Hall, Arrow on Trust, 26 J. HeAlTH PoL. PoL'y \& L. 1131, 1140-41 (2001); Larry E. Ribstein, Law v. Trust, 81 B.U. L. REv. 553, 576-86 (2001).

68. See, e.g., David Mechanic, The Functions and Limitations of Trust in the Provision of Medical Care, 23 J. HEALTH POL. POL'Y \& L. 661, 661-62 (1998) (discussing the threats HMOs pose to patients' trust in their physicians); David Mechanic \& Mark Schlesinger, The Impact of Managed Care on Patients' Trust in Medical Care and Their Physicians, 275 JAMA 1693 (1996) (warning that close association between physicians and managed care organizations can erode patients' trust in their physicians).

69. See Susan Rose-Ackerman, The Political Economy of Corruption, in CORRUPTION AND THE Global ECONOMY 31, 49 (Kimberly Ann Elliott ed., 1997) (analyzing corruption as, in part, a problem of superoptimal levels of trust within networks of public officials who are complicit in illicit self-dealing). 
rising managed care backlash. It is equally certain to disturb those who resist market allocation of health care in general. But ideology aside, Hall's case is deeply problematic, for reasons I will presently explain.

These reasons fall into two broad groups. First, his basic analytic framework-placement of health care regulatory policies into three categories, based on these policies' supposed relationship to trust ${ }^{70}$-entails a series of assumptions about these policies that favor antiregulatory conclusions. Hall neither defends these assumptions nor considers whether alternative understandings of these policies' purposes and impact might lead to different judgments about them. Second, social science findings about trust do not clearly support (or, for that matter, refute) the antiregulatory message he discerns in them. From a lawyer's perspective, a frustrating feature of research in this area is that different study designs often yield conclusions that pull in opposite policy directions. ${ }^{71}$ For example, some research suggests that legal requirements suppress people's cooperative inclinations, ${ }^{72}$ while other studies support the claim that law's expressive power can nurture cooperation. ${ }^{73}$ The behavioral science literature on trust and cooperation is open to criticism as a jumble of insights in search of a paradigm. From this jumble, Hall picks and chooses, in a manner consistent with his antiregulatory positions. He conveys his choices in tentative prose, at times acknowledging that social science insights might cut the other way. But these hedges do not divert him from thumbs-down judgment of much that courts and regulators have done, or might do. Moreover, he overreaches in inferring from survey research, including his own, that patient trust is less vulnerable (and less in need of the law's support) than most in the health sector believe. The surveys he cites do not support his case, and other research results contradict it.

\section{B. The Relationship Between Health Care Law and Trust}

Hall's division of health care law into three categories, based on averred relationships between law and trust, is the foundation for his reconstruction of

70. Hall, supra note 60 , at $485-86$.

71. Strictly speaking, of course, accurately reported research findings-the data themselves-do not contradict each other. If an experiment is precisely replicated, with identical research subjects and under identical circumstances, it will yield the same results. It is researchers' (or policy advocates') broader inferences from different results-results arising from nonidentical study designs-that frequently contradict, or at least pull in different directions. This problem is hardly limited to behavioral science research on trust; it pervades the law's use of insights from the social sciences.

72. See, e.g., Bruno S. Frey, How Intrinsic Motivation Is Crowded Out and In, 6 RationaliTY \& Soc'y 334 (1994) [hereinafter Frey, Intrinsic Motivation]; Bruno S. Frey, Institutions and Morale: The Crowding-Out Effect, in ECONOMICS, VALUES, AND ORGANIZATION, supra note 35, at 437 [hereinafter Frey, Institutions and Morale].

73. Robert Cooter, Do Good Laws Make Good Citizens?: An Economic Analysis of Internalized Norms, 86 VA. L. REV. 1577, 1597-1600 (2000). 
the case for contract. His categories represent "stances that law can take toward trust""74-"predicated," "supportive," and "skeptical."75 The predicated stance treats trust as a problem. It takes the existence of trust as a given, "inevitable for psychological reasons." "76 Because trust in health care providers "exceed[s] rational expectations," "77 Hall contends, the task for law that adopts this stance is to manage the disconnect between trust-inspired hopes and disheartening reality. The supportive stance assumes - often inaccurately, Hall says-that trust is more fragile. It treats trust as a virtue and tries to promote it, through measures that foster trusting sentiments and trustworthy behavior. The skeptical stance treats trust in health care payers and providers as undeserved and looks to complement or replace trust with intrusive regulatory alternatives. Hall places most managed care regulation, actual and proposed, ${ }^{78}$ in this category.

\section{Treating trust as a problem.}

Laws that treat trust as a problem target the tendency of trust to arouse unrealistic expectations, Hall says. Because failure to meet these expectations produces unrealistic disappointment, these laws punish violators in an attenuated manner, to avoid treating them unfairly. Medical malpractice law is Hall's primary example. It is intended, he asserts, to punish violations of trust. It is "not plausibly meant to sustain trust or to restore it once it is violated." 79 Hall analyzes malpractice law's deference to professional custom through this lens, contending that physician-set standards of care keep juries from imposing idealized expectations on doctors and health plans. ${ }^{80}$ He then extends this interpretation to many of the doctrinal turns in medical tort law that health plans and market-oriented scholars have urged over the past twenty years. These include high barriers to punitive damages, frequent reduction of jury verdicts, judicial reluctance to admit evidence of financial rewards for withholding care, and resistance to suits for breach of fiduciary duty based on such incentives. ${ }^{81}$ These trends, Hall argues, are justifiable responses to consumers' (and jurors') overreactions when they experience breaches of trust.

74. Hall, supra note 60 , at 486 .

75. Id.

76. Id. at 488 .

77. Id. at 489 .

78. This includes the competing "Patients' Bill of Rights" proposals now pending in Congress, as well as managed care regulation at the state level.

79. Hall, supra note 60 , at 491 .

80. Hall notes that courts have not adopted a "reasonable physician" standard, which, he avers, would "invite[] juries to impose their possibly unrealistic notions of what doctors should be able to accomplish." Id. at 492.

81. Id. at 493-95. 
Medical tort law may, to some degree, serve a punitive function, arising from the ideal of reciprocity between private parties. Some scholars argue that this is or should be tort law's main purpose, and that courts should not weigh social consequences that lie outside the lines of particular accident and injury cases in need of resolution. ${ }^{82}$ This appears to be Hall's position-his basis for saying that malpractice law is meant to punish breaches of trust and not to preserve or rekindle trust. But the prevailing view is that the sole or primary purpose of tort law is minimization of the social costs of injury. ${ }^{83}$ Tort law looks forward, toward overall social well-being, not backward, toward settling accounts for individual victims. To the extent that breach of trust is the type of injury at issue in medical tort cases, social cost minimization requires the law to focus on sustaining trust and trustworthiness. Hall's claim that malpractice law is not "plausibly" meant to do this is unsupported by argument 84 and contrary to the weight of recent tort jurisprudence. This jurisprudence takes the measure of medical liability, including liability for harm ensuing from breaches of trust, based on its ability to deter the type of injury at issue. ${ }^{85}$ Hall offers no assessment of the deterrence value of the liability rules he discusses. His characterization of malpractice law as a response to patients' unrealistic, trustdriven expectations assumes away the need to do so.

Moreover, Hall's focus on trust disregards malpractice law's declared deterrence target: bodily harm and the pain, suffering, and economic losses that result from it. Evidence suggests that malpractice law sends a weak deterrent signal, relative to the frequency of such harm. Studies comparing the incidence of malpractice claims to the frequency of episodes of medical negligence (as identified by research teams of medical record reviewers) have found that only small fractions of the identified negligence episodes result in

82. George P. Fletcher, Fairness and Utility in Tort Theory, 85 HARV. L. REV. 537, 569-71 (1972).

83. Landmark works developing this position from different perspectives include Guido Calabresi, THe Cost of ACCidents: A Legal and EConomic ANAlysis (1970); Richard A. Posner, ECONOMIC ANALYsis of LAW 179-83 (5th ed. 1998); and SteVEN ShaVell, ECONOMIC ANALYSIS OF ACCIDENT LAW (1987). During the second half of the twentieth century, this utilitarian vision came to prevail, in the RESTATEMENT (SECOND) OF TORTS (1965) (especially in the Restatement's approaches to setting standards of care in negligence cases, Sections 291-293, and determining reasonable levels of risk in products liability cases, Section 402A) and appellate opinions on negligence and products liability issues. See G. EdWARd White, TORT LAW IN AMERICA 178-79, 230-33 (1980) (discussing rise of utilitarian approaches to tort law).

84. Hall's sole citation for this claim is to a quotation from Blackstone's Commentaries, written two centuries before the turn in American tort doctrine toward the utilitarian perspective. See Hall, supra note 60, at 491 (quoting Blackstone's assertion that suits against physicians for "neglect or unskillful management" are allowed because such failure "breaks the trust" placed in the physician).

85. Paul C. Weiler, Medical Malpractice on Trial 70-73 (1991). Strictly speaking, increments of liability are desirable when their deterrence value outweighs their associated social costs (including costs of care and legal and other transaction costs). 
malpractice claims. ${ }^{86}$ Even smaller proportions of these identified episodes lead to monetary settlements and judgments. ${ }^{87}$ This evidence belies accounts of a malpractice system at risk of running amok, driven by anger at health care providers. ${ }^{88}$ But malpractice law's underdeterrence of bodily harm and its consequences is of little interest to Hall (at least in this article). By framing the task of medical tort law as the buffering of plaintiffs' (and jurors') overreactions to breaches of trust, he channels attention away from the law's underreaction to medical injury. 89

Even if one were to accept Hall's characterization of the purpose of malpractice law as the settling of accounts with betrayers of trust, his framing of medical tort law's task as management of overreaction to betrayal would be problematic. That sick patients can regress to childlike belief in medical omnipotence that far exceeds rational expectations ${ }^{90}$ is surely the case. Hall's understanding of this distinguishes him from other health care contractarians. They have been reluctant to acknowledge the transforming effects of illness on people's preferences and on their capacities for reasoned decisionmaking. This is hardly surprising: Contractarians fear this transformation's implications for the perceived legitimacy of both ex ante and ex post consumer choices. Hall, in

86. See Patricia M. Danzon, Medical Malpractice: Theory, Evidence, and PuBlic Policy 22-25 (1985) (finding, based on review of medical records from 20,000 patients hospitalized in California in the mid-1970s, that only one tort claim was filed for every ten episodes of negligence that resulted in disability); HARVARD MED. PRACTICE StUdy, Patients, Doctors, and LaWYers: MEdical INJURY, MalPractice Litigation, AND PATIENT COMPENSATION IN NEW YORK 4-13, 11-4 (1990) (finding, based on review of medical records from 31,000 hospitalizations in New York State in 1984, that only one tort claim was filed for every eight potentially valid claims).

87. DANZON, supra note 86 , at 25 (finding only one paid claim per 25 episodes of negligence in California Study); HARVARD MED. PRACTICE STUdy, supra note 86, at 11-4 (estimating only one paid claim per sixteen potentially valid claims in Harvard Study).

88. Hall concedes that the tort system fails to adequately detect medical negligence overall, Hall, supra note 60 , at 495 , but his focus is on the tiny proportion of malpractice cases that yield very large damage awards. He is persuasive in linking these large awards to jurors' anger, but his ascription of this anger to betrayal of trust is speculation.

89. A thorough discussion of the causes of avoidable medical injury and of the law's potential and limits as a tool for reducing the incidence of such injury is beyond my scope here. For a state-of-the-art review of causes and correctives for medical error, from the National Academies of Sciences, see generally COMM. ON QUALITY OF HEALTH CARE IN AM., InST. Of Med., To ERr is Human: BuILding a SAFer Health System (Linda T. Kohn, Janet M. Corrigan \& Molla S. Donaldson eds., 2000). Negligence doctrine is profoundly flawed as a medical risk management tool and may not be worth preserving. See generally DANZON, supra note 86 (discussing problems in the law's approach to specifying standards of due care and compensable damages); WEILER, supra note 85 (suggesting that a no-fault system would provide more effective prevention and more equitable compensation). But there is some evidence that the intensity of the malpractice litigation threat and the persistence of some of the legal rules opposed by market-oriented tort reformers have modest preventive effects on the incidence of medical injury. WEILER, supra note 85 , at 70 92.

90. Hall, supra note 60 , at 478 . 
contrast, offers a nuanced discussion of this psychological transformation and the resulting therapeutic and other benefits of trust. ${ }^{91}$ He accepts that childlike fantasies of doctors' omnipotence can have therapeutic value, akin to the placebo effect, and that these fantasies can impart a sense of safety and comfort. And I believe he is right (though I am biased by my self-interest in this matter ${ }^{92}$ ) to take the position that law should protect physicians against patient backlash when fantasies of perfection and omnipotence go awry.

But there is a difference between taking care not to hold doctors hostage to unrealistic expectations and countenancing interpersonal betrayal. Medical tort law can accomplish the former, by deferring to professional standards of care (as Hall suggests), or through a general reasonableness standard, with robust judicial supervision of juries. Medical tort law need not do the latter. It can defer to professional standards of care (or impose reasonableness through judicial constraints on juries) while insisting on doctors' fidelity to patients. Hall notes that revelations of financial incentives to withhold care have led to large jury verdicts, presumably resulting from moral outrage. He says these verdicts are overreactions to betrayal, and that law should avert this type of overreaction through such means as not telling jurors about doctors' financial incentives. This is a raw value judgment on Hall's part. Others, including myself, would be more inclined to treat people's strong reactions to this kind of betrayal as legitimate. To the extent that they are legitimate, law that aims to settle accounts should be less reserved about punishing infidelity than Hall is inclined to be.

Finally, Hall voices frustration over courts' refusal, so far, to agree to lower standards of care for patients who subscribe to cheaper managed health plans. ${ }^{93}$ He ascribes this refusal to the law's concern with trust-inspired expectations: Judges, he says, are inclined to vindicate expectations fed by insurers' promises to provide care regardless of cost. Were HMOs to openly proclaim their intent to ration care within their budgets (and were Americans to accept the reality of medical resource scarcity), ${ }^{94}$ trust-inspired expectations

91. Id. at $477-82$.

92. From my time in clinical medicine, I remember well some of my patients' unrealistic fantasies about what I could offer-and my worries about the prospect of disappointing them.

93. Hall is a long-time supporter of stratified standards of care, based on ability and willingness to pay for medical services. See, e.g., Mark A. Hall, Health Care Cost Containment and the Siratification of Malpractice Law, 30 JURIMETRICS J. 501 (1990) (arguing for judicial acceptance of economically stratified duties of care). This is a crucial agenda item for health care contractarians, since it would enable doctors, hospitals, and health plans to offer low-end care, at lower prices, without fear of ruinous liability. See, e.g., Epstein, supra note 16; cf. Morreim, supra note 16 (criticizing proposals for the contractual setting of standards of care but urging that health care providers be permitted to present evidence of resource constraints to rebut the presumption of a unitary, professional standard of care).

94. Writing two years ago for a unanimous United States Supreme Court, Justice David Souter proclaimed that health care rationing was both inherent in the design of prepaid health 
would not be an obstacle to economically stratified malpractice standards. I think Hall is right in predicting that honesty about rationing would take the trust barrier out of the picture (or at least downsize it). But the question of equity would remain. Hall's discussion of the law's resistance to stratified standards of care fails even to acknowledge this question's relevance. To the extent that Americans (including judges) conceive of medical care as a "merit good," that is, a thing to be allocated in a manner decoupled from the distribution of wealth, a shift to stratified standards of care would meet resistance. There is surely some hypocrisy in this. As a nation, we have declined, or failed, to provide medical insurance coverage for all. ${ }^{95}$ And, as health care contractarians often remind us, cheaper coverage, made possible by lower standards of care, would make insurance more accessible. But the uncovering of hypocrisy, arising from tension between our commitments to economic liberty and equity, does not warrant removing equity from the picture. It is in play, alongside trust, in the law's resistance to stratified standards of care. ${ }^{96}$

\section{Treating trust as a virtue.}

While Hall speaks favorably of laws that, he holds, treat trust as a problem and shield health care payers and providers from patients' trust-inspired expectations, he is skeptical of laws that take a "supportive stance" toward trust. Laws, actual and proposed, that he places in his supportive category treat trust as both fragile and desirable. They are vigorously interventionist, since they rest on the premise that market mechanisms cannot adequately safeguard trust. Hall's principal examples are regulatory schemes aimed at protecting medical information privacy and reducing health care providers' conflicts of interest. ${ }^{97}$ His main criticism of these regulatory approaches is that they are

plans and a matter of national policy (since Congress had enacted a statute fostering the development of HMOs). Pegram v. Herdrich, 530 U.S. 211, 220-22, 231-34 (2000). Justice Souter's blunt talk about rationing provoked considerable press coverage. See, e.g., Robert Pear, The R Word: Justice Souter Takes on a Health Care Taboo, N.Y. TIMES, June 18, $2000, \S 4$, at 3 . But the balancing of benefits against costs and the withholding of beneficial care to meet budgetary constraints are not yet acknowledged in health plan advertising or subscriber contracts.

95. As of 2001, approximately forty million Americans lacked health insurance coverage. U.S. Census Bureau, Health Insurance Coverage: 2000, at http://www. census.gov/hhes/hlthins/hlthin00/hlt00asc.html (last revised Aug. 22, 2002).

96. It is, in truth, unlikely that people in low-end health plans, with bureaucratic barriers to elite specialty care and/or primary care doctors with large financial incentives to practice frugally, receive the same levels of care as do people in high-end plans. The law's unitary standard of care may thus be a fiction. But, if so, it is a fiction that serves to reduce the real gap between low-end and high-end levels of care.

97. He also examines physician-assisted suicide through this lens. See Hall, supra note 60 , at 500-03. Space constraints preclude my considering this subject here, but were I to do so, I would raise concerns similar to those that I take up in this Part. 
unneeded because trust is more resilient than is generally supposed. They therefore impose pointless costs, by blocking private actors' efforts to achieve socially desirable objectives. Beyond this, he suggests that laws compelling trustworthy conduct may have the paradoxical effect of suppressing people's intrinsic motives to act in a trustworthy manner. Less visibly, by putting regulatory schemes in his supportive category, he frames consideration of their merits in a manner that excludes other arguments on their behalf.

Trust versus other justifications for regulation. I shall address this last concern first. It is most evident in Hall's discussion of legal protection for health information privacy. A large body of scholarship and caselaw treats privacy as a right, important for personal dignity and psychological welfare. ${ }^{98}$ The law's protection for medical privacy follows from this more general right. ${ }^{99}$ Yet Hall disregards both the existence of this right and its grounding in the law's concern for citizens' dignity and mental well-being. Neither the therapeutic privilege nor federal health information privacy regulation, he contends, are premised, in the main, on a right to privacy. Rather, they are "explicitly premised on the therapeutic need to reassure patients that they can trust their physicians ...."100 Thus all that matters for Hall in evaluating the need for these (and other) legal protections for medical privacy is whether these safeguards do in fact promote trust. ${ }^{101}$ The actual protection these safeguards provide for citizens' privacy interests does not count within Hall's evaluative framework, since these interests, in themselves, are not part of his framework.

Hall is on stronger ground in treating regulation of physicians' financial incentives as law meant to support trust. Critics of monetary rewards to doctors for withholding care have focused on the question of betrayal of trust. ${ }^{102}$ But

98. Review of the voluminous literature on the right to privacy is beyond my scope here. But this much is clear: Since the origins of the right in Warren and Brandeis's classic article, its principal rationale has been protection against mental distress and loss of liberty resulting from invasion of privacy. Samuel D. Warren \& Louis D. Brandeis, The Right to Privacy, 4 HARV. L. REV. 193, 196 (1890). Although the constitutional dimensions of the right to privacy have received much discussion in recent decades, the right began as a tort concept, and emotional distress ensuing from its violation has propelled the right's development in tort law. See generally William L. Prosser, Privacy, 48 CAL. L. REV. 383 (1960) (discussing the development of the law of privacy through an examination of privacy cases since Warren and Brandeis's article). (1995).

99. Lawrence O. Gostin, Health Information Privacy, 80 CORNELL L. REV. 451, 494-99

100. Hall, supra note 60 , at 499 . To support this proposition, Hall cites: (1) language in federal health information privacy regulation discussing what he calls the "perceived need" to reassure patients in order to take advantage of the efficiencies of computerized medical data, id. n.144, and (2) language from Jaffee v. Redmond, 518 U.S. 1 (1996), justifying the psychotherapist-patient privilege in terms of the need for trust to enable treatment to succeed, Hall, supra note 60, at 499.

101. Id. at 505-06.

102. See, e.g., Brief of Amici Curiae Health Law, Policy, and Ethics Scholars at 16-20, Pegram v. Herdrich, 530 U.S. 211 (2000) (No. 98-1949) (urging that fiduciary duty provisions in ERISA be construed to limit HMOs' financial rewards to physicians for frugal 
these incentives raise other concerns. They have the potential to reduce the intensity and/or quality of care to socially undesired levels. They make health care rationing less visible, and in the eyes of some, less legitimate, than it would be were it to be done based on detailed contractually or legally mandated allocative rules. By making rationing less visible, they obscure the stratification of standards of care according to economic class. This lowers the profile of health care equity concerns on the political agenda. And by making cost management a matter of individual physicians' discretion, they create more room for stereotypes, biases, and differential empathy that engender racial and ethnic disparities in care. ${ }^{103}$ Finally, laws mandating disclosure of physicians' incentives promote patient autonomy by giving consumers some say concerning these incentives. None of these concerns count within Hall's evaluative framework, except insofar as they have spillover effects on patient trust.

The resiliency of trust. Hall's chief complaint about regulatory schemes he says are meant to foster patients' trust is that this support is unnecessary. He contends that empirical research, including his own, does not substantiate the premise that trust is put at risk by the breaches of medical privacy, financial incentives, and other health care industry practices he considers. Here, he overreaches. He leaps too facilely from this negative claim-that the data fail to support the hypothesis of trust-at-risk - to the judgment that trust is resilient, indeed a "resource... which can be expended without serious depletion,"104 and to the surmise that much trust-promoting regulation is unneeded. 105

The surveys Hall reviews set out a weak case for the proposition that physicians' financial incentives and other managed care cost control practices do not put patient trust at risk. ${ }^{106}$ Telephone surveys done by Hall's team and

practice); M. Gregg Bloche, U.S. Health Care After Pegram: Betrayal at the Bedside?, HeAlth AfFaIRS, Sept.-Oct. 2000, at 224, 225.

103. See Comm. On Understanding \& Eliminating RaCial \& ETHNic DisParities IN Health Care, Inst. of Med., Unequal Treatment: Confronting RaCial and ETHNiC Disparities In Health Care (Brian D. Smedley, Adrienne Y. Stith \& Alan R. Nelson eds., 2002), available at http://www.nap.edu/books/030908265X/html (hereinafter INST. OF MED., UNEQUal TREATMENT); M. Gregg Bloche, Race and Discretion in American Medicine, 1 Yale J. Health Pol'y L. \& EThics 95, 115 (2001) (discussing ways in which cost containment strategies contribute to racial disparities in health care provision).

104. Hall, supra note 60 , at 526 .

105. He hedges carefully here, by conceding multiple limitations in the studies he reviews, $i d$. at 506, by acknowledging that he has not proven that trust is as resilient as he suspects; and by remarking that "those who advocate supportive legal measures should not have to bear the burden of proving their case empirically." Id at 509. Yet elsewhere, he takes the resiliency of trust as a given, $i d$. at 508 , and suggests (albeit in language softened with frequent use of "may" and "can") that trust-promoting regulation should be viewed with "caution" and should have "weak or nondirective enforcement mechanisms." Id. at 509, 511.

106. Space constraints preclude my discussing the several surveys Hall mentions that were conducted in the late 1970s and early 1980s to examine the effects of the psychotherapist-patient evidentiary privilege and the Tarasoff rule (requiring 
others show that respondents' faith in the fidelity and ability of their personal physicians remained high through the 1990 s, ${ }^{107}$ despite rising public criticism of managed care. Phone surveys, though, have serious limitations as tools for probing people's underlying structures of belief and their hopes and anxieties. 108 Subjects' instant, unreflective reporting of their impressions in response to a string of brief questions cannot capture the strength or fragility of these impressions-or the layers of understanding that generate these impressions. Use of focus groups and in-depth, semi-structured interviews by political consultants and market researchers to craft campaign and product promotion messages reflects this limitation.

Psychology and economics researchers have observed that people's surface beliefs about many things tend to remain relatively stable for long periods, punctuated by rapid shifts. People's adherence to social norms ${ }^{109}$ and investors' valuations of stocks and other assets 110 illustrate this tendency. Cognitive and emotional change beneath the waterline of expressed preferences sets the stage for such surface-level shifts but is only dimly understood. To the extent that trust in the health sphere behaves in this fashion, telephone survey questions are unlikely to detect its impending collapse-until it is too late.

psychotherapists to warn potential victims when patients make serious threats of violence) on people's willingness to seek treatment. Id at 505 . But my concerns about his inferences from these studies are similar to the concerns I will presently discuss, in the managed care context.

107. See Mark A. Hall, Beiyao Zheng, Elizabeth Dugan, Fabian Camacho, Kristin E. Kidd, Aneil Mishra \& Rajesh Balkrishnan, Measuring Patients' Trust in Their Primary Care Providers, 59 Med. Care Res. \& Rev. 293 (2002); Audiey C. Kao, Diane C. Green, Alan M. Zaslavsky, Jeffrey P. Koplan \& Paul D. Cleary, The Relationship Between Method of Physician Payment and Patient Trust, 280 JAMA 1708 (1998). The survey done by Hall's team yielded highly positive (favorable) responses to questions to consumers about their doctors' fidelity to patients in the face of financial and other pressures from health care payers.

108. Hall's study team grasped this problem and tried to compensate for it, by using focus groups to probe people's understanding of the trust issues raised by prospective questionnaire items. The team selected and modified items based on this focus group inquiry, then pilot-tested its selected items, then conducted qualitative interviews with eight pilot test respondents to examine their understandings of the items. The items were then modified again. Hall et al., supra note 107, at 298-99. Hall's team, in short, appears to have done the best it could, within the limits of the telephone survey genre. Had the team employed focus groups and qualitative interviews as research tools in themselves, rather than as methods of crafting and selecting survey items, it might have penetrated more deeply into subjects' understandings, hopes, and fears.

109. See Sushil Bikhchandani, David Hirschleifer \& Ivo Welsh, A Theory of Fads, Fashion, Custom, and Cultural Change as Informational Cascades, 100 J. POL. ECON. 992 (1992) (discussing sudden shifts in previously stable customs and cultural norms), cited in Cass R. Sunstein, Social Norms and Social Roles, 96 ColuM. L. REv. 903, 912 n.30 (1996).

110. Abhijit V. Banerjee, A Simple Model of Herd Behavior, 107 Q.J. ECON. 797, 800 (1992) (discussing "excess volatility" in many asset markets); In Ho Lee, Market Crashes and Informational Avalanches, $65 \mathrm{REV}$. ECON. STUD. 741, 753 (1998) (suggesting that markets are likely to be more volatile after long periods of stability). 
Signs that trust is at high risk in the health sphere are more evident than Hall acknowledges. The enormous anti-managed care jury verdicts that Hall dismisses as overreactions to betrayal are sentinels of this risk. Cases in which jurors learn of previously hidden financial incentives to withhold care are natural experiments-tests of people's responses to infidelity in the medical realm. The anti-managed care backlash in the press, Congress, and state legislatures has been driven by the disconnect between promises of professional fidelity and needed care and the realities of conflict of interest and pressure to set limits. Indeed, one prominent health care contractarian has endorsed limited patient protection legislation as an antidote to distrust of managed care. 111

Physician reports of rising patient distrust are another worrisome sign that Hall disregards. A 1997 nationwide survey of more than 1500 midcareer physicians found that more than half believed that changes in their work environments over the previous five years had adversely affected their patients' trust. 112 Physician-respondents who reported an overall financial incentive to limit services were more likely than others to report diminished patient trust. ${ }^{113}$ One might discount these findings as "nonspecific indicators of physician dissatisfaction with change, or as a reaction to diminished professional autonomy."114 On the other hand, physicians are better situated than any other observers to pick up overt and subtle signs of their patients' distrust. ${ }^{115}$

There is, moreover, evidence that patients who belong to racial and ethnic minority groups experience less trust in their physicians than do white

111. Clark C. Havighurst, The Backlash Against Managed Health Care: Hard Politics Make Bad Policy, 34 IND. L. REV. 395, 409-16 (2001). Another study by Hall's survey research team underscores the managed care industry's risky disconnect between promise and reality: Telling health plan subscribers about their physicians' financial incentives to practice frugally increased these subscribers' self-reported trust in their doctors. Mark A. Hall, Elizabeth Dugan, Rajesh Balkrishnan \& Donald Bradley, How Disclosing HMO Physician Incentives Affects Trust, HEALTH AfF., Mar.-Apr. 2002, at 197, 204. This result is consistent with a causal connection between disingenuity and distrust.

112. Daniel P. Sulmasy, M. Gregg Bloche, Jean M. Mitchell \& Jack Hadley, Physicians' Ethical Beliefs About Cost-Control Arrangements, 160 ARCHIVES INTERNAL MED. 649, 651-52 (2000). This study employed survey methodology similar to that used by Hall's research team: Items were developed and selected with focus group guidance, then refined by professional survey designers using cognitive pretesting techniques. See id. at 650 .

113. Id. at 653 (inferring from multivariate regression analysis). More than three quarters of the survey's respondents indicated that they believed financial incentives "designed to encourage physicians to be more restrained in their use of medical resources for individual patients" are ethically unacceptable. $I d$. at 651.

114. Id. at 653 .

115. Patients' reports concerning their trust in their physicians have been found to be highly correlated with physicians' perceptions of that trust. Robert F. St. Peter, Access to Specialists: Perspectives of Patients and Primary Care Physicians, CENTER FOR STUDYING Health Sys. Change Data Bull., Fall 1997, at 1-2. 
patients. ${ }^{116}$ Hall discounts the likelihood and significance of such a trust gap, ${ }^{117}$ but numerous studies suggest its existence and clinical impact. An Institute of Medicine examination of this literature found correlations between physician-patient racial concordance and a wide range of empirical indicators of the quality of the doctor-patient relationship, including measures of physician verbal dominance, patient satisfaction, and participatory decisionmaking and patient-centered care. ${ }^{118}$ To the extent that these indicators correlate with patient trust (and there is reason for believing that they $\mathrm{do}^{119}$ ), there is a connection between trust and physician-patient racial concordance. ${ }^{120}$ Given that white patients are more likely to visit same-race physicians than are patients in racial minority groups, ${ }^{121}$ any link between trust and doctor-patient racial concordance translates into a trust gap between white and minority Americans.

My point is not that health law and policy should pursue the goal of increased physician-patient racial concordance. Efforts to achieve this by means other than increasing the representation of racial minorities in the medical profession would be problematic for many reasons. My point, rather, is that we have reason to believe that minority patients feel less trustful in clinical settings than do their white counterparts. There is, moreover, good reason to suspect that this trust gap makes a clinical difference. Beyond the therapeutic potential of trust and the sense of security that comes from faith that the doctor is on our side, there is the link between trust and treatment refusal. Several studies have found that African-American patients are less likely than whites to agree to invasive, technology-intensive treatments. ${ }^{122}$ Whether this disparity is due to a black-white trust gap cannot be answered with currently

116. See INST. OF MED., UNEQUAL TREATMENT, supra note 103, at 105-11.

117. Hall, supra note 60 , at $507 \mathrm{n} .181$ (concluding that findings of a statistically significant relationship between trust and patient race have not been "consistent across studies" and "are not of a very large magnitude").

118. See generally INST. OF MED., UNEQUAL TREATMENT, supra note 103. In addition to patient surveys, these studies drew upon analyses of audiotapes of doctor-patient visits.

119. Hall's empirical work supports this point: He detects close correlation between patients' "global trust" and their impressions of physician competence, and he in turn notes that other studies have found that patients tend to assess physician competence based upon their impressions of doctors' interpersonal skills. See Hall et al,, supra note 107, at 313.

120. Hall appears to deny such a connection, asserting that doctors' race has "little or no impact on trust, even when ... matched with patients' demographics." Hall, supra note 60 , at 508 .

121. The likelihood of racial concordance between minority patients and their physicians is diminished not only for the obvious reason that being in a minority in an integrated society makes one less likely than majority group members to encounter samerace professionals, but also because racial minorities tend to be underrepresented among American physicians, in proportion to these minority groups' presence in the overall population. INST. OF MED., UNEQUAL TREATMENT, supra note 103, at 106-09.

122. Id. at 110-11. Racial differences in treatment refusal rates, it should be noted, do not fully explain racial disparities in the medical care that Americans receive. Id. at 141. 
available data. ${ }^{123}$ But to the extent that these treatments yield desirable health outcomes, this possibility is troubling.

"Crowding out" trust. Hall bases another set of arguments against managed care regulation on the behavioral economics literature concerning the "crowding out" of intrinsic motivation to cooperate. Contributors to this genre emphasize the potential of both legal mandates and market incentives to suppress intrinsic, noncalculative motives. ${ }^{124}$ Hall focuses almost exclusively on the former. "Patients" Bill of Rights" provisions, he contends, risk promoting self-interested physician and health plan behavior by signaling to doctors and insurers "that they are not in fact trusted and are not expected to act on the basis of intrinsically trustworthy motivations." 125 Hall's inattention here to an equal and opposite implication of the "crowding out" literature-that incentives to skimp on care and referrals can suppress physicians' fidelity to patients and plan administrators' good faith concerning coverage issues-is stunning. 126

His claim that regulation, all regulation of managed care, ${ }^{127}$ produces only literalistic compliance "to the extent of actual enforcement" 128 disregards another large theme in the behavioral science literature on law: law's power to strengthen people's internal commitment to rules of conduct. ${ }^{129}$ Law gains

123. The possible connections between patient distrust (including perceptions of racial discrimination, aversion, or disregard) and treatment refusal, or expressed preferences for less intensive treatment, are enormously complex and difficult to disentangle for empirical study. The interplay between patients' and providers' behavior and attitudes during the clinical encounter, and the impact of these interactions on the care that members of different racial groups receive, are similarly challenging to comprehend. Id. at 137-38.

124. See, e.g., Frey, Intrinsic Motivation, supra note 72, at 335-37; Frey, Institutions and Morale, supra note 72, at 443-44. This literature's central premise is that calculative motives-sensitivity to deterrence signals, opportunities for reciprocity, etc--are not enough to explain trustworthy conduct, team play, and other cooperative behaviors. A shortcoming of this literature (in my view) is that it does not develop and test psychological models-cognitive, affective, or otherwise-for how "crowding out" occurs.

125. Hall, supra note 60 , at 509-10.

126. Hall, moreover, extends his "crowding out" claim beyond the reach of "crowding out" logic, by asserting that the detailed protections in "Patients' Bill of Rights" proposals "could easily convey to patients the impression that HMOs and their doctors cannot be trusted." Id. at 509 . This is a claim-utterly speculative-about the expressive function of law, but it does not involve law's "crowding out" of target actors' intrinsic desires to act in a trustworthy fashion. The target actors for these legal protections are clinicians and managed care administrators, and it is their motives to be trustworthy that may or may not be crowded out. The separate effects of these legal protections on patient trust (and patients' perceptions of trustworthiness) are relevant to assessment of such laws but are not a matter of "crowding out."

127. He refers here to all regulation contained in "Patients' Bill of Rights" proposals, it would appear, since he doesn't single out any particular regulatory approach for discussion.

128. Id. at 510 .

129. See Blair \& Stout, supra note 38, at $1785-89$ (concluding that fiduciary relationships created by the law build a foundation for psychological commitment to trustworthy conduct within these relationships); Sunstein, supra note 41, at 2024-25 (1996) 
enormous leverage, far beyond the state's commitment to enforcement, when target actors embrace the norms law expresses. Hall references this literature and acknowledges this point; indeed, he notes the success of banking and insurance regulation in reconstructing business trustworthiness and consumers' trust. 130 This vision of law's relationship to people's intrinsic motivation is the converse of the "crowding out" thesis. For anyone seeking insight into how a regulatory scheme might function in practice, these two, opposed behavioralist propositions pose a dilemma: How are we to predict whether a law will fortify or undermine people's internal motives?

Hall concedes the need to address this question, but he then miscasts it, in a way that ordains answers hostile to robust legal protection for health care consumers. He does so by framing the task as one of "distinguish[ing] between law's regulatory and expressive functions," 131 rather than determining whether a law will reinforce or undermine target actors' internal motives to comply. This leads him, unsurprisingly, to urge "broad standards rather than detailed rules" and "weak or nondirective enforcement mechanisms."132 He thus criticizes judicial review of medical coverage decisions, ${ }^{133}$ laws barring health plans from limiting what doctors can tell patients, ${ }^{134}$ and laws requiring disclosure of financial incentives to reduce costs ${ }^{135}$ as regulatory approaches that express skepticism of trust and thereby undermine it.

More provocatively, Hall suggests a strategy he calls "lip-service respect for the law," under which "trust-related laws are commonly violated at the same time that their underlying principles continue to be used for rhetorical advantage."136 Disjunctions between loftily stated principle and the operation of law in practice are a common means of philosophical and political compromise. ${ }^{137}$ But such compromise is unstable. There is a thriving market

(exploring "the expressive function of law-the function of law in 'making statements' as opposed to controlling behavior directly" and discussing "how legal 'statements' might be designed to change social norms").

130. Hall, supra note 60 , at 516-18.

131. Id. at 511.

132. Id. He cites Dan M. Kahan, Gentle Nudges vs. Hard Shoves: Solving the Sticky Norms Problem, 67 U. CHI. L. REV. 607 (2000), for this proposition, but Kahan, more than Hall, grounds his case for "gentle nudges" on discussion of the connections between the law's "nudges" and "shoves" and the psychology of target actors' internal motives. See id. at $641-43$.

133. Hall, supra note 60 , at 515 .

134. Id. at 517,519 .

135. Id. at 514-15.

136. Id. at 511 .

137. Such compromise can arise both from society's commitment to absolute principles that are contradicted by other needs (e.g., commitment to the pricelessness of life and to economic development that entails risk, see generally GUIDO CALABRESI \& PHILIP BOBBITT, TRAGIC CHOICES (1978)), and from political dealmaking (e.g., regulatory statutes with sweeping, idealistic preambles, written to satisfy social activists, and multiple, arcane loopholes, designed to allay industry objections). 
for exposure of political and legal contradiction. Scholars, journalists, political advocates, and litigators take delight in revealing it, and their respective audiences pay handsome rewards, in prestige, recognition, and money. Revelation disrupts covert philosophical and legislative deals, and conflicts that were put to rest through disjunction between the law's rhetoric and the law in action reemerge.

For society's most painful philosophical and political choices, unstable compromises of this sort may be the best that we can do. But the instability of these deals makes their constituent statements of principle into poor vehicles for law's expressive function. And exposure of repeated failure to honor the law's promises corrodes the sense of reciprocity that is needed for trust and trustworthiness to emerge in voluntaristic fashion in ongoing relationships. ${ }^{138}$ Cynicism is the more likely message, and distrust of the law the more likely result.

\section{Regulation as distrust.}

Hall constructs a separate category of laws skeptical toward trust by treating robust regulation of managed care as premised on the industry's untrustworthiness. Most regulation of the industry, he holds, constitutes "institutionalize[d] distrust," rather than an effort to shore up its trustworthiness. ${ }^{139}$ Regulation built on the premise that health care institutions cannot be trusted signals patients to withhold their trust, he contends. Hall then reminds readers of the therapeutic importance of patient trust: Ergo, he says, institutionalizing distrust through law is a bad idea. Therefore, taking managed care as a given, ${ }^{140}$ we should eschew aggressive regulation of the industry in favor of less intrusive strategies that will, by avoiding the "crowding out" problem, foster trustworthiness and trust.

To characterize regulation of managed care as premised on the industry's untrustworthiness and as expressive of distrust, Hall casts regulation as a bid to create "a confidence-building substitute for trust."141 Requiring HMOs to tell patients about rewards to doctors for limiting care, he claims, presumes that

138. See Ernst Fehr, Simon Gachter \& Georg Kirchsteiger, Reciprocity as a Contract Enforcement Device: Experimental Evidence, 65 ECONOMETRICA 833, 833 (1997) (arguing that "reciprocal behavior may cause an increase in the set of enforceable contracts and may thus allow the achievement of nonnegligible efficiency gains"); Matthew Rabin, Incorporating Fairness into Game Theory and Economics, 83 AM. ECON. REV. 1281 (1993) (presenting data and models bearing on roles of reciprocity and fairness in development of cooperative relationships).

139. Hall, supra note 60 , at 512 .

140. That he takes the managed care industry as a given is clear from his response to frank distrust of the industry by proponents of government-sponsored, single-payer medical coverage as an alternative. Their opposition to the industry on trustworthiness grounds, he says, "is equivalent to curing an infectious disease by killing its host." Id.

141. Id. at 515 . 
physicians with such incentives are untrustworthy. ${ }^{142}$ In addition, he says, independent review and judicial scrutiny of medical coverage decisions substitute trust in review panels or courts for trust (or lack thereof) in insurers. ${ }^{143}$ But Hall's characterizations of these and other regulatory measures are hardly self-evident. Mandatory disclosure of incentives to doctors to limit treatment could just as easily be characterized as both autonomy-regarding and trust-promoting. Indeed, Hall's own research supports this alternative characterization. His telephone survey team found that informing HMO subscribers about their physicians' financial incentives to limit care increased these subscribers' self-reported trust in their doctors. ${ }^{144}$

Likewise, outside review of coverage decisions could just as easily be characterized as supportive of trust in insurers. Recent evidence is consistent with this: In states that mandate independent administrative review of medical coverage denials, the right to review is rarely invoked. ${ }^{145}$ The managed care indusiry's endorsement of mandatory independent review ${ }^{146}$ is likewise consistent with the thesis that such review fosters trust in health plans. Hall might reply by asserting (as he does elsewhere) ${ }^{147}$ a distinction between trust and confidence, then claiming that review of coverage denials fosters the latter, not the former. Some commentary supports the drawing of such a line, based on the role of emotive versus calculative thinking about fidelity and reliability. 148 But current psychological thinking favors a blurring of this line. Deepening understanding of emotional influences on our values, preferences, and calculative reasoning 149 is consistent with a holistic account of trust and confidence as a set of interconnected feelings and beliefs. ${ }^{150}$ Such an account

142. Id. at 514 .

143. Id. at 515 .

144. See Hall et al., supra note 111, at 203.

145. See Raja Mishra, Shortage of Cases for HMO Agency, Boston Globe, Jan. 27, 2001 , at A1. An additional explanation for the low frequency of independent review requests might be greater insurer willingness to authorize coverage at earlier stages, in anticipation of the possibility of independent review.

146. See Stephanie Kanwit, General Counsel of the American Association of Health Plans, Remarks at the Acadamey of Health Services Research and Health Policy Annual Meeting, Roundtable Session: "Beyond the Patients' Bill of Rights: The Law \& Politics of Managed Care" (June 25, 2002) (explaining that AAHP endorses federally mandated independent review) (audiotapes on file with Academy of Health Services Research and Health Policy).

147. Hall, supra note 60, at 513-14.

148. See generally Williamson, supra note 4.

149. See generally DAMASIO, supra note 34; Jorge L. Armony, David ServanSchreiber, Jonathan D. Cohen \& Joseph E. LeDoux, Computational Modeling of Emotion: Explorations Through the Anatomy and Physiology of Fear Conditioning, 1 TRENDS CoGNITIVE SCI. 28 (1997); Loewenstein et al., supra note 34.

150. Hall's own, empirically based account of trust is holistic in this sense: It draws upon survey respondents' self-reporting concerning their doctors' fidelity, competence, honesty, and keeping of confidences. Hall's survey research team found that respondents' answers to questions designed to measure their beliefs within each of these categories 
makes it implausible to contend that a law can promote confidence in an institution (or individual) while undermining trust. In short, Hall's characterization of managed care regulations (or at least those he targets: external review of coverage decisions and mandatory disclosure of financial incentives) as "institutionalize[d] distrust" is speculative and against the grain of the available evidence.

\section{CONCLUSION: MARKETS FOR TRUST AND BETRAYAL}

Mark Hall's central claim about the law governing the medical marketplace is that it risks being too solicitous of patients' trust. "Ethics and public policy tend to treat patient trust as a precious species," he protests. ${ }^{151}$ "[A]nother view of trust produces a radically different conclusion"-that "trust in physicians should be viewed as a resource," to be "expended without serious depletion to do much of the heavy lifting required by health care policy." 152 Cost containment is the heavy lifting that most needs to be done, he holds, and doctors should not shy away from doing it. Physicians, not insurers or government, should ration care at the bedside because the medical profession is a "more resilient repository of trust."'153

Citing Robert Putnam, Hall draws a parallel between trust and social capital: Both do a great deal of heavy lifting in a healthy society. 154 This is more than an apt analogy. Trust is a crucial constituent of social capital. ${ }^{155}$ The generalized reciprocity that mutual trust makes possible reduces stress and transaction costs, fostering physical and social well-being. ${ }^{156}$ But this reciprocity, or social trust, rests on mutual trustworthiness. ${ }^{157}$ It is jeopardized by betrayal-by one-sided failure to meet mutual expectations. ${ }^{158}$ This is the central flaw in Hall's argument, and it is the danger his prescription presents.

Hall wants physicians to do the heavy lifting of cost control by drawing upon the trust they have accrued through the profession's commitment to fidelity to patients. But bedside rationing, done covertly via professional

correlated closely with each other, to the extent that the team formulated a fifth variable, "global trust," closely correlated to the other four and expressive of the one-dimensionality of medical trust. Hall et al., supra note 107, at 312-13.

151. Hall, supra note 60 , at 526.

152. Id.

153. Id.

154. Id. \& n. 248 .

155. See PUTNAM, supra note 12 , at 19-26, 134-47.

156. See id. at 135.

157. See id. at 136.

158. Curiously, Hall seems to realize that people take much umbrage over betrayal, since he interprets a good deal of medical tort law as a means for managing people's overreactions to betrayal. See supra text accompanying notes 79-92. This makes it puzzling that he fails to acknowledge the threat to medical trust posed by betrayal of expectations at the bedside. 
discretion, does not square with this commitment to fidelity. It breaks faith with patients, and the thriving market for exposure of contradiction between avowed commitment and covert realities ensures that this will be found out. ${ }^{159}$ Hall is wrong about trust's resilience in the face of such discovery-wrong in denying that the calculated breaches of faith he urges will result in trust's depletion.

But does this mean aggressive regulation is the only preventive against potential breaches of faith and other disappointed consumer expectations? I think not; indeed, I argue elsewhere that regulation plays only a subsidiary protective role. ${ }^{160}$ Markets, in this regard, work better than many market proponents recognize. As Kenneth Arrow observed forty years ago, there is a market for professional trustworthiness: Ethical commitment to fidelity to patients and self-control over financial self-interest are "part of the commodity the physician sells."161 There is also a market for institutional trustworthiness and reliability. Institutions, especially health care payers, have become much more powerful in the medical sphere since Arrow made his observations, and consumer awareness of this power translates into consumer demand for trustworthiness and reliability.

There are, moreover, markets for betrayal, or, more precisely, markets that detect, expose, and punish it. There is monetary and psychic reward for revelation of political and legal contradiction, 162 and there are payoffs for those who spotlight inconsistencies between what private actors promise and do. ${ }^{163}$ To the extent that dismay over these inconsistencies influences consumers' health care and coverage choices, markets penalize betrayals of trust and confidence. Investors' ongoing efforts to anticipate and respond to consumers' medical care and coverage preferences magnify the economic cost of consumer dismay for firms that rely upon capital markets. 164

Health care payers', providers', and investors' efforts to anticipate regulatory and legal change are another large influence upon these actors' market choices. Through the 1990s, anticipation of political and legal developments (e.g., enactment of a federal "Patients' Bill of Rights") that did

159. See supra text accompanying notes 137-38.

160. M. Gregg Bloche, One Step Ahead of the Law: Market Pressures and the Evolution of Managed Care, in The Privatization of Health CARe Reform: Legal AND RegulatoRy PERSPECTIVES, supra note 21.

161. Arrow, supra note 26, at 965.

162. See supra text accompanying notes $137-38$.

163. Public officials (and candidates for political office), litigators, investigative journalists, political activists, and even investment advisors are on the lookout for such inconsistency in the private sphere, and their varied audiences reward them with reputational and financial benefits.

164. The investment community has taken a keen interest in consumer responses to health plans' administrative practices, coverage options, and other cost-control strategies. Investors' assessments of consumer reaction, both observed and expected, are a powerful influence upon firms that depend on debt and equity markets. See Bloche, supra note 160. 
not in fact occur played a bigger role in bringing about health systems change than did actual legislative or judicial intervention. ${ }^{165}$

These interconnected markets play out in raucous fashion, chaotic beyond the capacity of game theorists to model and predict. But in general, they push health care payers and providers away from arrangements that betray or otherwise break with consumer expectations. During the mid and late 1990s, they pushed health plans away from frequent denial of services on medical necessity grounds, ${ }^{166}$ and they may now be nudging plans away from financial incentives to physicians to limit care. ${ }^{167}$

Markets for medical trustworthiness are notably unstable, judging by the experience of the past 100 years. Professional commitment to the ethic of undivided loyalty to patients and suppression of self-interest has fluctuated widely since the late nineteenth century, as has consumer demand for signs of this commitment. ${ }^{168}$ The turn-of-the-twentieth-century medical marketplace was a cacophony of unabashed commercial claims for unproven nostrums. Consumer skepticism about physicians' therapeutic claims and financial motives was a staple of popular culture. ${ }^{169}$ But by the $1920 \mathrm{~s}$, the medical profession, concerned about its credibility, was well on its way toward suppressing commercialism and asserting its ethical commitments to fidelity and quality. By the $1950 \mathrm{~s}$, public trust and confidence in the medical profession was at a historic high. 170 A new equilibrium of consumer belief and expectation had become established, more favorable to the profession than were the expectations of commercialism early in the century. But having won Americans' trust, the profession was under less pressure to prove its trustworthiness. During the 1960 s and 1970 s, physicians took opportunistic advantage, investing in hospitals, laboratories, and other businesses. Commitment to the ethic of suppression of self-interest flagged. The $1980 \mathrm{~s}$ and 1990 s saw a return to frank commercialism with parallels to the medical entrepreneurship of 100 years ago. ${ }^{171}$

165. $I d$.

166. Id.

167. Cara S. Lesser \& Paul B. Ginsburg, Back to the Future? New Cost and Access Challenges Emerge, ISSUE BRIEF (Center for Studying Health Systems Change), Feb. 2001, at 4 , available at $\mathrm{http} / / \mathrm{www} . \mathrm{hschange.com} / \mathrm{CONTENT} / 295 /$.

168. Bloche, supra note 29 , at 1108 .

169. George Bernard Shaw's scathing account of physicians' materialistic motives in his 1906-produced comedy, The Doctor's Dilemma, is illustrative of this skeptical ethos. Bernard Shaw, The Doctor's Dilemma, Getting Married, and The Shewing-up of BLANCO POSNET (1911).

170. Paul Starr, The Social Transformation of American Medicine 335-37 (1982).

171. Similarities include aggressive advertising, price competition, quality claims, and seeming unself-consciousness about commercial methods and motives. The chief differences lie in the units of competition (between individual clinicians and other sellers of nostrums 100 years ago; between managed health plans, hospitals, and other large firms, for the most part, today) and in the regulatory environment (quality claims and market entry are 
These shifting patterns of professional self-restraint and patient trust and confidence are an object lesson for anyone inclined to presume trust's resiliency. They caution that downward cascades of trust and trustworthiness are a possibility. But they also hold out hope that consumer (and investor) demand for trustworthiness can prevent such cascades. Indeed, this demand can help to reconstitute lost trustworthiness, trust, and confidence-if those whom consumers want to trust seize the entrepreneurial opportunity.

Does regulation have a role to play in promoting trustworthiness in the health sphere? To answer this question is to confront an irony: Citizen demand for laws to promote trustworthiness parallels consumer demand in the medical marketplace. Popular concern about whether doctors and health plans can be trusted translates into both political pressure for regulation and market pressure on medical care providers and insurers to eschew trust-eroding practices. Thus, as a practical matter, we may see either overlapping, perhaps duplicative political and market responses to trust-endangering practices or (if the public is little-concerned about trust) neither a political nor a market reaction. Scholars' "either-or" discussions of regulatory versus market solutions to problems tend to disregard the real-world truth that we often end up with either both or neither, depending on the intensity of popular concern. ${ }^{172}$

This is not to say that regulation has no role. Trustworthiness-enhancing mandates can surmount market failures, and they can extend the benefits of trustworthiness to consumers who lack the buying power to insist on trustworthy clinical and administrative practice. Beyond this, such mandates may have a powerful expressive function ${ }^{173}$ - they may help to inculcate and reinforce trustworthy norms of clinical and administrative conduct. Public debate over proposed regulation, moreover, can both inform consumers about untrustworthy market practices and mobilize them to avoid health plans and providers that engage in them. Debate over regulatory proposals thus ameliorates information and collective action problems, enabling markets to work better, ${ }^{174}$ even when regulation is not enacted.

Assessment of regulatory proposals should pay heed to their benefits for narrow interest groups at the public's expense. Doctors' and hospitals' ongoing efforts to win antitrust law exemption for price-setting practices are

more tightly restricted today, by tort and contract law, licensing, and myriad consumer protection statutes).

172. An illustration of the both-or-neither phenomenon is the enactment, in most states, of statutes granting patients a right to independent review of managed care coverage denials, Rush Prudential HMO v. Moran, 122 S. Ct. 2151, 2178 (2002) (Thomas, J., dissenting), while managed health plans were cutting back sharply, during the late $1990 \mathrm{~s}$, on the incidence of such denials, in response to subscriber dissatisfaction, Bloche, supra note 160 .

173. See text accompanying notes $40-42$.

174. There is a downside risk here as well: Public debate can mislead consumers about the incidence and effects of controversial industry practices, resulting in welfare-reducing consumer choices. 
illustrative. ${ }^{175}$ Sorting out such special interest advocacy from proposals that promise wider benefit is exceedingly difficult, as public choice theorists are wont to point out, especially since public officials with ties to affected interests are often the ones doing the sorting out. More visible advocacy by scholars and researchers who are free of such ties can make a valuable contribution in this regard, by informing decisionmakers (and voters) and by raising the political cost attached to interest group giveaways.

There remains the challenge that Hall and other health care contractarians have set as their main focus-containment of medical spending. As taxpayers, health insurance purchasers, and price-conscious shoppers for goods and services, we demand medical cost control-from government, our own health plans, and the businesses we patronize. That we resist these controls when we and our loved ones face life-threatening or life-changing illness is, for contractarians, the central dilemma of health care policy. Hall's call for covert bedside rationing challenges his critics to come up with an alternative approach to this dilemma.

Elsewhere, I contend that the contractarians' insistence on according trump value to people's ex ante health care choices - the decisions they make, often by default, when they buy health insurance-is at odds with core human needs that we look to medical care to meet. ${ }^{176}$ Needs for care and respect, protection against abandonment, and preservation of hope for rescue in dire circumstances engender health care spending well in excess of levels we would choose ex ante. ${ }^{177}$ The challenge for health law and policy is to mediate between the dispassionate, efficiency-oriented reasoning associated with the ex ante perspective and our emotive, fearful, and hopeful thinking at moments of medical crisis. A caring society, responsive to people's hopes and fears as expressed through both democratic and market means, will spend more on medicine than might seem wise, ex ante. A robust society, able to take the long view of its members' interests and needs, will find ways to avoid the resource depletion that ensues from giving carte blanche to people in dire circumstances.

I have argued in this Comment that disingenuity as first resort is an unwise approach to the conflict between our ex ante and our later, illness-endangered selves. Not only does rationing by tacit deceit raise a host of moral problems, it will not work, over the long haul, because markets reward deceit's unmasking. The honesty about clinical limit-setting that some bioethicists urge ${ }^{178}$ may not

175. See Hammer, supra note 21.

176. Bloche, supra note 43.

177. Id.

178. See e.g., Daniel Callahan, What Kind of Life: The Limits of Medical PROGRESS 261-62 (1990) (arguing that lack of open discussion about health care priorities has led us to "spend too much on health in comparison with other social needs, too much on the old in comparison with the young, too much on the acutely ill in comparison with the chronically ill, too much on curing in comparison with caring, too much on expensive individual health needs in comparison with less expensive societal health needs, and too 
be fully within our reach. But more candor is possible than we now achieve, and the more conscious we are about decisions to impose limits, the more inclined we will be to accept them without experiencing betrayal.

Law can help in this regard, by nudging us toward more conscious medical spending choices. The Supreme Court's pointed observation two years ago, in Pegram v. Herdrich, that HMOs control spending by rationing care ${ }^{179}$ was a step in this direction. The Court's immunization of health plans from malpractice suits when restrictions on medical coverage and care are made explicit to health plan subscribers through ERISA benefit descriptions 180 is another nudge toward conscious choice. This selective liability shield invites health plans to break out of their business-as-usual practice of setting limits covertly, via opaque, "medical necessity" language in insurance contracts and financial incentives to providers to withhold care. Additional legal rewards for directness and penalties for opacity should be a major focus of managed care reform.

Law can encourage more candid limit-setting, but it cannot force-feed conscious choice to consumers who don't want to face it. The psychology of denial ensures an unavoidable minimum of anger and bitterness when health care payers and providers fall short of unfounded expectations. By nudging our culture toward more conscious acceptance of limits, health law can ease, but not eliminate, this anger and bitterness. Remaking health law as a tool for limit-setting by deceit, on the other hand, would lead to downward cycles of anger and distrust, with tragic consequences for medicine's healing potential.

much on extending the length of life rather than enhancing the quality of life").

179. See Pegram v. Herdrich, 530 U.S. 211, 221 (2000) (declaring that "inducement to ration care goes to the very point of any HMO scheme").

180. See supra note 24 . 